\title{
Utilizing Industry-led Innovation Capacity to Enhance Supply Chain Performance: An Empirical Study
}

\author{
Maree Storer (Corresponding author) \\ UQ Business School, University of Queensland \\ \& \\ Cooperative Research Centre for Beef Technologies, \\ Colin Clark Building, Blair Drive, University of Queensland, St Lucia Queensland 4072, Australia
}

Tel: 61-7-3225-8080 Email: m.storer@business.uq.edu.au

Professor Paul Hyland

School of Management, Queensland University of Technology

Tel: 61-7-3138-2938 Email: paul.hyland@qut.edu.au

Received: September 23, 2011

Doi: $10.5539 /$ mas.v5n6p55

\author{
Accepted: October 8, 2011 \\ Published: December 1, 2011 \\ URL: http://dx.doi.org/10.5539/mas.v5n6p55
}

\begin{abstract}
A fundamental principle of the resource-based (RBV) of the firm is that the basis for a competitive advantage lies primarily in the application of bundles of valuable strategic capabilities and resources at a firm's or supply chain's disposal. These capabilities enact research activities and outputs produced by industry funded R\&D bodies. Such industry lead innovations are seen as strategic industry resources, because effective utilization of industry innovation capacity by sectors such as the Australian beef industry is critical, if productivity levels are to increase. Academics and practitioners often maintain that dynamic supply chains and innovation capacity are mechanisms most likely to deliver performance improvements in national industries. Yet many industries are still failing to capitalise on these strategic resources. In this research, we draw on the resource-based view (RBV) and embryonic research into strategic supply chain capabilities to investigate how two strategic supply chain capabilities (supply chain performance differential capability and supply chain dynamic capability) influence industry-led innovation capacity utilization measured through perceptions of supply chain operatives of superior supply chain performance enhancements. Two models compare the influence of size of supply chain operatives on these factors and their relationships. Results indicate that both small and large supply chain operatives in this industry believe these strategic capabilities influence and function as second-order latent variables of strategic supply chain capability. Additionally the study confirms that size of the supply chain operative influences how the respondents perceived strategic capabilities influence supply chain performance enhancement expected from utilizing industry-led innovation capacity in this industry.
\end{abstract}

Keywords: innovation, RBV, supply chain management, strategic capability, performance differentials, dynamic capabilities

\section{Introduction}

National industries rely on their supply chains and innovation capacities to deliver sustainability and enduring global competitiveness. However, only limited empirical research combines both topics, particularly in terms of investigating innovation capacity within mature industry supply chains (Burgess, 2007). Adding to this, supply chain studies continue to maintain a narrow focus, reflecting the views of only one or a small number of supply chain participants (Hult et al., 2002). Taking that approach does not reflect the true nature of a supply chain. A supply chain consists of many interdependent business relationships who collectively, at specific points in time, transform raw materials into finished products for an ultimate consumer, (Lambert et al., 1996; Lamming et al., 2006; Mabert and Venkataramanan, 1998). Hult et al. (2002, p.577) note: "links in a chain may be within a single organization's borders and others may cross such borders in unpredictable and evolving ways. Thus empirical insights that are drawn from multiple chain participants are needed to understand the efficiency enhancement possible through supply chain management". 
A strategic management philosophy supports this research, through a body of multi-disciplinary studies underpinned by the Resource-Based View (RBV). The supply chain is examined as an 'organizational form' in its own right (Hult et al., 2004), characterized by common understandings between operatives. These include the adoption of strategies of integration in aspects of their operations through the use of technology; and the view that supply chain links are flexible and may be severed as required.

To date, much of the research in this area has been somewhat intuitive, with limited empirical testing of concepts. Pockets of work exist, such as the strategic or best value supply chain model (Ketchen Jr. and Hult, 2007), supply chain orientation (Hult et al., 2008) and supply chain cultural competitiveness (Hult et al., 2002). This study therefore seeks to increase the presence of empirical research and contribute to this existing embryonic body of work in the area of strategic supply chain capability (Ketchen Jr. and Guinipero, 2004; Ketchen Jr., and Hult, 2007), by defining and measuring two specific strategic supply chain capabilities - supply chain performance differential capability (Bharadwaj, 2000; Wu et al., 2006; Zott, 2003); and supply chain dynamic capability (Chang et al., 2008; Danneels, 2008; Eisenhardt and Martin 2000; Storer and Hyland, 2010). It also seeks to examine how they influence innovation capacity utilization from an industry perspective. The concept of innovation capacity utilization in this study refers to exploiting new ideas or inventions (for example the widespread use of the Internet and electronic business solutions), and exploiting them to improve supply chain performance. The industry context is the Australian beef industry and its supply chain, and the influence of the size of the supply chain operative is also examined. This is due to the predominance of small enterprise across the supply chain. Although generalization of results may be limited, these new and insightful findings should contribute to both supply chain management and innovation management literature as well as to improving supply chain practices in this industry.

In order to direct this investigation efficiently, a research framework and hypotheses were developed and tested using Confirmatory Factor Analysis (CFA) and Structural Equation Modelling (SEM) as the research methods. The key research question to be answered is, how do strategic supply chain capabilities influence utilization of industry-led innovation capacity and its ability to provide performance enhancements in the Australian beef industry? The following sections describe relevant background literature and hypotheses development, the proposed model, the methodology and analysis of the research, together with implications of the study. Suggested future research directions are also discussed.

\section{A Resource-Based View}

Within the resource-based (RBV) literature, major trends are based on representative works of three key perspectives: 1. Dynamic Capability perspective (Eisenhardt and Martin, 2000; Helfat and Peteraf, 2009; Nelson and Winter, 1982; Rumelt, 1987; Teece et al., 1997b; Wernerfelt, 1984); 2. Knowledge-Based View (KBV) (Grant 1996; Kogut and Zander, 1992); and 3. Relational View (RV) (inter-organizational relations) (Dyer and Singh, 1998). The basis for the RBV approach stems from many studies, predominantly from a strategic management approach (Barney, 2003; Williamson, 1999), where it is argued a competitive advantage lies primarily in the application of bundles of valuable strategic capabilities and resources at a firm's disposal. These embedded capabilities lie within strategic relationships present in a firm at any particular point in time.

From an RBV perspective, a supply chain represents an "organizational form" in its own right (Ketchen Jr., 2003; Ketchen Jr. and Guinipero, 2004; Ketchen Jr. and Hult, 2007; Ketchen Jr. et al., 2007). This "organization form" has a variety and pattern of participant relationships that seek to prosper from their contributions to the supply chain. The structure within should provide a social structure for cooperative or collaborative behaviour where information can be shared, activities coordinated, and joint innovation activities undertaken, as required. The common goals of a supply chain should bring them together, with technology utilized as a support mechanism to meet key tasks, deadlines, and demands for customers. Unfortunately, this is not always how many supply chain operatives behave!

Innovation capacity building in the Australian beef industry is often funded through State and Commonwealth Government grants and industry levies. Industry associations such as Meat and Livestock Australia (MLA), and the Australian Meat Processing Organization (AMPC) also play important roles in this process, along with the Cooperative Research Center (CRC) for Beef, which was created to undertake large, longer-term collaborative research and development (R\&D) activities in beef research. Resultant research outputs from all these sources are considered strategic resources for the industry, and are expected to drive global, superior performance. This study investigates the influence of wide-spread use of the Internet and Electronic Business Systems across Australian beef supply chains. Being a traditional agricultural industry, the use of this type of technology was not seen an strategic to enhancing performance capacity across the industry until 2001, even though other industries had acknowledged this type of innovation as critical to productivity increases and strategic competitive 
advantage much earlier (Buhalis, 1998; Utterback, 1982). Other industry sectors found that innovating in this way could result in more effective and efficient information sharing; greater controls over quality assurance across the supply chain through tracking and tracing of product; and the ability to speed up transactions and lower transaction costs ; and collaborative forecasting and planning (Wu et al., 2006). These types of e-business systems are also referred to as supply chain communication systems and e-management systems (Wu et al., 2006). It should be noted however, that while there have been positive results, some industries have reported mixed results (Wang et al., 2006), particularly in this industry where it has been suggested this strategic resource is not being fully explored nor utilized by all members of the industry. This result may be accounted for due to variances in strategic capability in the industry, which may not have been accounted for.

\section{Strategic supply chain capabilities}

As mentioned earlier, supply chain capabilities are defined through an RBV lens as those capabilities required by supply chain operatives to identify, utilize and assimilate both internal and external resources and information to facilitate the normal course of business supply chain activities (Amit and Schoemaker, 1993; Bharadwaj, 2000; Collis, 1994). Strategic supply chain capabilities however, are a higher-order supply chain resource (Godfrey and Hill, 1995), defined as capabilities that have the capacity to influence important supply chain outcomes over and above the normal course of business (Hult et al., 2002). Strategic supply chain capabilities can incorporate capabilities such as, integrated information exchange, systems level coordination, inter-firm activity integration and supply chain responsiveness (Wu et al., 2006). They can also include strategic and competitive capabilities such as organizational resource bundling, reconfiguration and synchronization capabilities within the supply chain (Black and Boal, 1994; Teece et al., 1997b). These strategic capabilities are not always evident within all chain operatives (Hult et al., 2008) and can vary across operatives. As mentioned earlier, research in this area is embryonic, however, strategic supply chain capabilities such as, supply chain orientation (Hult et al., 2008) and supply chain cultural competitiveness (Hult et al., 2002) have been identified. This research examines the existence of two other strategic supply chain capabilities, supply chain performance differential capability, and supply chain dynamic capability. We argue these capabilities are strategic to the supply chain and that they influence the utilization industry-led innovation capacity and its benefits. We also propose that the size of the supply chain operative impacts on this process.

\section{Hypotheses}

As suggested in the introduction, a research framework guides this research presented in Figure I. It outlines the intent to examine the influence of the two (2) proposed strategic supply chain capabilities on utilizing innovation capacity and its benefits. The first strategic supply chain capability examined, relates to the strategic differences that exist in performance capability between the various supply chain operatives within the Australian beef supply chain. Supply chain performance differential capability operationalized as a second-order latent construct, is measured using composite indicators of, control, resources, risk, and complexity. The second strategic supply chain capability examined, incorporates the dynamic responsiveness and reaction capability of supply chain operatives in this industry, to changing market requirements. We operationalized Supply chain dynamic capability through composite indicators identified as, reconfiguration, collaboration, adaptability, and agility. Industry-led innovation capacity utilization, also a higher order construct, is operationalized by the level of benefit supply chain operatives believe is achieved through this innovation utilization, through composite indicators - financial benefit, operational efficiencies, and growth factors. Data is split to then compare two models to understand how size of the supply chain operative influences these relationships.

\section{Supply Chain Performance Differential Capability}

Performance differentials are present within individual supply chain actors due to their heterogeneity (Peteraf, 1993) and from an RBV view, they represent the unique resource combinations present within, which are often difficult to imitate (Stoelhorst and Van Raaij, 2004). However, the supply chain context can influence these differentials, due to the inter-organizational nature of supply chain activities (Dekker, 2004; Dyer and Singh, 1998). Their impact is often also influenced by the size of the individual supply chain operative (Audretsch and Vivarelli, 1996; Bowen, 2002; Goode and Gregor, 2009), and as Schumpeter suggests, the role of innovation (Galunic and Rodan, 1998). Through an RBV lens, supply chain performance differentials are strategic and heterogeneous to each supply chain operative, and include intrinsic and extrinsic capabilities. As discussed previously, supply chain performance differential capability is operationalized using four first-order indicators, the first being the level of control within the supply chain operatives to deal with internal and external dynamics. The second relates to the level of access or availability of resources such as e-resources with supply chain operatives. The third involves the risk strategies adopted in terms of dealing with market dynamics and internal 
and external relationships by the supply chain operatives. The final indicator refers to the level of complexity operating with various supply chain operatives at any given time.

'Control' in this study is adapted from Cox (1997). He maintained it is the ability of the supply chain to maximize advantage of, and monitor all of its critical assets. This ensures the supply chain can sustain and maintain its' ability to appropriate and accumulate value for its participants through flexibility in design, and by processing information accurately and efficiently (Cox, 1997). Also supply chain control is not confined within the legal boundaries of a single organization (Newman et al., 2009). Often the differentiation of control within the supply chain leads to increased costs and structures within the chain, resulting from demand for increased monitoring between chain participants (Hopwood, 1996). One of the most difficult challenges facing the supply chain in relation to control is determining the structural design of the supply chain in a dynamic way to meet the changing demands in the market. Important sources of control and structure can reside within a group of supply chain actors through dynamic information sharing, underpinned by dynamic innovation capacity (Nonaka, I. and Takeuchi, 1995). In the Australian beef industry, degrees of control may fluctuate due to the size of the supply chain operative (Cohen and Klepper, 1996; Nieto and Santamaria, 2010). Differences in scale reside between the domain of the multi-national and large-scale national operators and the micro/smaller operators, together with fluctuating capability and differentiated access to strategic industry resources.

'Resources' are defined as the tangible and intangible capacity resulting from the relationships between supply chain operatives (Hitt et al., 2000), and as mentioned earlier are difficult to imitate (Hult et al., 2007). Supply chains respond to market demand by joining valuable tangible and intangible resources in order to deploy competences (Srivastava et al., 2001), but with small and large scale operations, access to these resources is uneven. In resourcing terms, some supply chain operatives dominate others, often preferring integrated operations with specific supply chain partners , 2000). This domination can cause disparities in resource utilization within the supply chain and often supply chain discontent is a result (Simatupang, T. M. and Sridharan, R., 2005). Poorly endowed supply chain participants are required to either adapt and align with the resource requirements driven by market demand or decouple from the chain. Especially as increasingly, e-resources are being relied upon by supply chains to improve performance through more efficient and effective communication and by facilitating speed, transparency and an ability to reduce costs and share capacity across chains (Jie et al., 2007; Stevensonand Spring, 2007; Wilson and Clarke, 1998).

'Risk' is understanding, and managing uncertainty, in the various physical, human, and organizational capital present within the supply chain as an organization. Risk is present constantly, due to internal or external vulnerabilities of supply chain operatives. It requires integrated risk management strategies across chain participants (Tang, 2006a, b), and is compounded by the variations in risk taking behaviour between supply chain operatives. Some authors suggest the variation in scale or size of each supply chain participant often underpins the variation in risk profiles between supply chain actors, with some actors more risk averse than others (Arrow, 1962). In the Australian beef industry, risk taking is often related to trust issues across a number of critical areas: information sharing; reliability, timeliness; customisation; and work standards; together with issues of lack of adoption of new technologies (Paterson, 2006). Additional risk also exists where there is a lack of mutuality afforded to smaller supply chain operatives due to the level of market power that can often reside with larger supply chain actors (Simatupang and Sridharan, 2005). In this industry, scale often creates a disproportionate risk sharing between the larger and smaller operators. Smaller operators often acquire resources and complexity within their operations more suited and related to their larger supply chain counterparts. This is a consequence of the smaller operatives trying to remain competitive in the industry. Disproportionate risk sharing and not recognising risk factors such as unsynchronised decision-making, information asymmetry, misaligned incentives and fragmented business processes often negatively affect supply chain performance (Simatupang and Sridharan, 2005).

'Complexity' is described as the inter-organizational levels and settings in place across the supply chain organization relating to the access, availability, and quality of both extrinsic and intrinsic assets of the supply chain, at a given point in time. Complexity levels can arise in the individual supply chain operative or can be due to the nature and structure of supply chain relationships. There are often goal incompatibilities (Lee et al., 2010) characterized by a lack resources and capabilities; an inability to fund innovations, such as using the Internet and EBS; poor cash flow; and low levels of internal skills (Devaraj et al., 2007; Krause et al., 2007, Sabath and Fontanella, 2002). For the Australian beef industry complexity varies in terms of business activities, innovation capacity, and also geographical dispersion of chain participants. For example, large numbers of supply chain participants operate in remote areas of Australia, as part of the beef industry supply chain. Additionally, in this industry there is complexity through industry divergence, where moderately dynamic (Eisenhardt and Martin, 
2000) activities relate to the processing of commodity beef cuts for domestic and global consumption. While extremely complex, high velocity (Eisenhardt and Martin, 2000) activities relate to processing by-products from the first process and value-adding into by-products, co-products and derivative beef products for domestic and global customers. In relation to exploiting and exploring the industry-led innovation capacity mentioned widespread use of the Internet and EBS, complexity can reside in the incompatibility of information, technology and communications (ICT) systems (Devaraj et al., 2007). Simple issues such as, inadequate on-line bandwidth and telephone infrastructure typical in more remote production areas, or the lack of synchronization of ICT systems with other supply chain operatives can cause this incompatibility. Complexity also relates to the ability of some supply chain actors being able to embrace radical and disruptive innovation, while others cannot. In this case the negative effects could result in strategic supply chain malfunctions due to misaligned information sharing, mismatched operational functions, processes and systems, and a break-down in strategic cooperation and collaboration across whole-of-industry supply chain activities (Lee, B. et al., 2010). Therefore, the following hypothesis is proposed:

H1: The strategic supply chain capability - supply chain performance differential capability - which is a second-order latent variable made up of first-order indicators - control, resources, risk and complexity influences the strategic supply chain resource - industry-led innovation capacity utilization?

\section{Supply Chain Dynamic Capability}

The second strategic supply chain capability discussed in this study, is supply chain dynamic capability. Theory surrounding dynamic capabilities, as strategic capabilities, has developed from an RBV perspective. However, ongoing debate exists as to what constitute dynamic capabilities and whether they can be measured through empirical study (Helfat and Peteraf, 2009). Some suggest dynamic capabilities are routines that provide dynamic improvement and strategic insight that enable organizations to react to change in their external environments (Collis, 1994; Eisenhardt and Martin; 2000; Teece et al., 1997b; Zollo and Winter, 2002). They enable highly context-specific and firm-dependent outcomes, which can provide a competitive advantage, while diminishing over time, if not utilised (Eisenhardt and Martin, 2000). Others suggest they involve the core processes of learning, reconfiguration, coordination and integration as concurrent processes which enable new combinations of competences and resources to be developed, deployed and protected (Teece et al., 1997a). Another view is that dynamic capabilities provide a reactionary platform for the renewal of capabilities by exploiting pre-existing knowledge or exploring new knowledge-based competences, internally and externally (Prieto and Easterby-Smith, 2006).

Regardless, the core competences integral to creating dynamic capability appear to be, sensing and learning (adaptation); coordination (alignment); integration (collaboration); and reconfiguration (Menon, 2008; Pavlou and Sawy, 2006). More recently, Ketchen et al., (2007) described dynamic capability in the context of a 'best value' supply chain model, defining higher order supply chain capabilities that ensure the intra- and inter-organizational relationships within the chain have the capability to react to market conditions and meet supply chain competitive priorities. These capabilities included systems investment, strategic relationship coordination, integration, adaptation, agility, and alignment (Ketchen Jr. and Hult, 2007). Storer and Hyland (2011) add support to this argument with their empirical study examining supply chain dynamic capability and innovation capacity. They suggest supply chain dynamic capability is a reactionary capability within supply chains, unlike innovation capability which is pro-active and planned (Storer and Hyland, 2010). We argue that dynamic capability provides the supply chain with higher order capability to meet specific supply chain challenges outside of normal routines. This capability provides the supply chain with qualities to respond rapidly to change in market conditions, at any particular point in time. Therefore, for the purposes of this research, we operationalized supply chain dynamic capability, as a higher order construct, through four first-order indicators as measures of this construct - reconfiguration, collaboration, adaptability and agility.

'Reconfiguration' unlike the processes of adapting, or agility, is the process of changing existing configurations of resources into new ones that match the changing environment (Menon, 2008; Pavlou and Sawy, 2006). Menon (2008) argues that reconfiguration as a capability has been connected to the appropriateness (Galunic and Rodan, 1998), timeliness (Zott, 2003) and efficiency (Kogut and Zander, 1992) by which existing resources are reconfigured by business operatives into new operational competencies.

'Collaboration' as a core process of supply chains relates to the ability of supply chain operatives to coordinate and integrate activities, systems and processes that help the deployment of reconfigured resources (Menon, 2008). This may involve seeking partnerships in an attempt to reduce costs, improve service and gain competitive advantage, however, not all partnerships are beneficial, and nor are they appropriate in all situations (Lambert et al., 1996). Without successful coordination, which involves managing dependencies among 
resources and tasks in order to create new ways of performing a set of activities (Crowston and Kammerer, 1998), collaboration is difficult. Collaboration adds a layer of complexity that coordination does not. It requires supply chain operatives, at a given point, to maintain control and independence, while sharing information and innovation capacity, aligning and integrating communication systems with other operators, in order achieve a single organizational framework to meet customer needs.

'Adaptability' on the other hand is sensing or learning when there is a need to reshape business practices and direction in the supply chain in response to market dynamics, and achieve this without ties to legacy issues or previous habits (Ketchen Jr. and Hult, 2007; Lee, 2004). Considered an important capability, it ensures ongoing sustainable supply chain practices that allow supply chains to meet new or changing consumer trends and demands; particularly in relation to the rising level of sophistication required in the information systems that inform these shifts and trends. These technologies have the potential to provide quality, transparent information, and ensure feedback loops on demand and supply. Supply chain information needs to loop from research and design to production to manufacturing to consumption, and is relevant to this industry, which participates in complex global food supply chains. Supply chain operatives are always facing increasing pressure to lower costs; adapt to changes in supplier agreements; adjust to changes in where manufacturing facilities are located; or shifts to outsourcing models by some suppliers, in order to satisfy remain competitive. In some cases the supply chain is replicated for the same product to ensure distribution (Ketchen Jr. and Hult, 2007). The Australian beef supply chain is part of a global beef supply chain, with various global distributors ensuring consumer demand is met, and ensuring alternate beef supply chains are always available from other countries, should there be any issues with supply.

'Agility' however, refers to speed. as it relates to a supply chain's ability to react and adapt to market forces, particularly rapid shifts in supply and demand (Lee, 2006; Van Hoek, Harrison and Christopher, 2001). Hult et al. (2002; 2003) suggest that an important ingredient in developing agility in supply chains is to develop "cultural competitiveness" - the level of predisposition within a supply chain to detect and fill gaps between what the customer desires and what is current offered. As Ketchen et al. (2007) notes, having cultural competitiveness within a supply chain ensures operatives share the vision and values important to the chain's competitiveness and omit irrelevant behaviours that are not in the best interests of end-users. This suggests agility is tied to the level of entrepreneurial, innovation within supply chain operatives and their willingness to share understandings and learning with other supply chain operatives on a dynamic and reactive basis to meet market changes at a point in time (Hult et al., 2002). Therefore, the following hypothesis is proposed:

H2: The strategic supply chain capability - supply chain dynamic capability - which is a second-order latent variable made up of first-order indicators - reconfiguration, collaboration, adaptability and agility - influences the strategic supply chain resource - industry-led innovation capacity utilization?

\section{Industry-led Innovation Capacity Utilization}

'Industry-led innovation utilization, within the scope of this research, is a higher-order competence by which supply chain operatives in a particular industry, exploit, explore and utilize new and improved resources, resulting from industry-led research and development (Rothaermel, 2001). In this particular case, the Australian beef industry and its supply chain operatives must be able to utilize the Internet and EBS, for improved communications, more transparent quality assurance, smarter business systems and better coordination across supply chain activities, if they are to grow, and show operational and financial benefits. Although opening up the industry and its supply chains to these technologies is a major innovation for this industry, it also poses very specific challenges, particularly taking size of the supply chain operative into consideration. Although ICT can provide a combination of higher-order resources and capacity, they also challenge the collective physical facilities and skills of employees, including senior management, to benefit from this capacity (Chandler, 1990). Utilizing resources such as the Internet and EBS comes with large exposures to risk and has profit implications. Solutions can often affect day-to-day operations of the supply chain and can impose penalties on parts of the chain. We therefore hypothesize the following:

H3: Within supply chains, industry-led innovation capacity utilization is positively correlated to improved supply chain growth, operating efficiencies and financial benefit?

\section{Operative Size}

Size of individual supply chain operations, within an industry supply chain, can differentiate business operations (Goode and Gregor, 2009; Hausdorf and Duncan, 2004; Kaufman et al., 2000; Kotey and Folker, 2007; Nieto and Santamaria, 2010; Rogers, 2004). It can also affect the capacity to innovate (Alessandro, 2007, BaldridgeV. and Burnham, 1975, Damanpour, 1992, Fennell, 1984). Size, by definition, is a construct variable described as 
an abstract entity which represents the true, non-observational state or nature of a phenomenon (Bagozzi and Fornell, 1982). It can be quantified using one or more indicators, and is a popular construct when investigating the use of information systems (IS). However, its use overall has been inconsistent (Goode and Gregor, 2009). There is evidence to suggest size affects utilization of innovation, particularly radical innovation with disproportionate benefits occurring between large and small operatives (Assink, 2006, Mansfield, 1968). Some argue large operative benefit more due to their critical mass which is seen as an advantage (Baldridge, J. V. and Burnham, 1975), along with their increased sophistication of communication systems both internally and externally (Robertson and Gatignon, 1987; Saren, 1987). However, cooperation and collaboration between partners, through research and development (R\&D) agendas, may bridge this gap (Nieto and Santamaría, 2010). Size as a structural variable has also been used to examine issues such as dynamic capability and its impact on overall performance (Eisenhardt, K. M. and Martin, J. A., 2000), and market power as a result of R\&D expenditure (Mabert et al., 2003). However, little of this work relates to supply chains and understanding how size affects the supply chain operative and their capacity to benefit from industry innovation capacity (Burgess, 2007; Burgess et al., 2006; Nieto and Santamaría, 2010). In this industry, there is a predominance of small agri-business operations across all aspects of the supply chain. Therefore the agricultural small business Estimated Value of Agri-business Operations (EVAO) definition provided in the Australian Bureau of Statistics (ABS) Report 1321.0, Chapter 1, page 2, has used to split the dataset, and create a mediating variable - size of supply chain operative. Small supply chain operations are defined as having an earnings of between AUD22 500 and AUD400 000, with large operatives defined as having earnings of between AUD400 001 and over (A.B.S., 2001). Therefore the following hypothesis is proposed:

H4: Strategic supply chain capability and the ability of the supply chain to utilize industry-led innovation capacity and its benefits is impacted by the size of the supply chain operative?

\section{Methodology}

Due to the complexity of this topic, this study forms part of a larger mixed method case study of the Australian beef industry and the impacts of industry-led innovation capacity. It examines and measures the presence of two strategic supply chain capabilities and their influence on utilizing this innovation capacity as a strategic resource to enhance supply chain performance. An a priori assignment of inter-variable relationships has been undertaken with Confirmatory Factor Analysis and Structural Equation Modelling (as a confirmatory approach to data analysis) used to test the hypothesized model statistically to determine the extent the proposed model is consistent with the sample data from industry (Wisner, 2003). The model incorporates both observed (indicator variables that can be measured), and unobserved (latent variables that cannot be measured directed and are inferred or hypothesized from the indicator variables) in both a structural and a measurement model. The structural equation model provides an assessment of predictive validity, specifies the direct and indirect relations among the latent variables, and describes the amount of explained and unexplained variance in the model. The measurement model specifies how the latent variables are measured in terms of the indicator variables and addresses the reliability and validity of the indicator variables in measuring the latent variables or hypothetical constructs (Hoyle, 1995; Maruyama, 1998; Schumacker and Lomax, 1996).

\section{Survey Data Collection}

The process for developing the survey instrument, its measurement constructs, and the 'best fit' model to answer the research questions outlined, follows the instrument development process recommended in Hair et al. (2010). Scale development followed acceptable procedures set out by Churchill (1979), with each construct clearly defined in terms of what would be included or excluded. Relevant scales and measures were adopted or adapted from the existing literature where appropriate, and if none were available or appropriate, new measures were developed (Churchill, 1979). Items were measured using a 5 point Likert Scale and were specifically developed, as part of the survey instrument for this study, set out in Appendix 1.

Data collected for this research resulted from a postal survey instrument sent to 2400 Australian beef industry, supply chain participants, across various industry categories, representing the majority of activities undertaken by the supply chain. All mailings, including a cover letter, the survey and a postage paid return envelop were sent via registered mail. Within four weeks of the initial mailing, follow-up was undertaken through telephone calls or emails to any respondents who had not replied, as suggested in Dillman's total design method (Dillman, 1978). Table 1 outlines an analysis of the respondents.

The Non-response bias was checked by comparing early and late respondents (Armstrong and Overton, 1977) using t-tests which revealed there was no significant differences on major constructs between the two groups. Therefore, it was accepted there were no significant issues with a non-response bias for this study. This study was also tested for common method bias using the Harman one-factor test with no dominant factor emerging, 
and therefore it was concluded there was no presence of common method bias in the study (Podsakoff and Organ, 1986). The final number of responses with no missing items was 412 responses. This represented a response rate of $17.2 \%$ and deemed acceptable for a survey of this nature. Both PAWS Statistics V18.0 (IBM Company, Chicago, III, USA) and AMOS V18.0 (Analysis of Moment Structures, AMOS Development Corporation, Spring House, Penn., USA) software programs were used to undertake multivariate analysis research on this data.

\section{Analysis: Construct Evaluation And Model Fit}

Confirmatory Factor Analysis (CFA) was used as a first step for testing both construct validity and theoretical relationships among the set of concepts represented by the multiple measured variables in this research (Hair Jnr, et al., 2010). CFA also confirmed the 'best-fit' or 'non-fit' of data and provided a method to determine the extent to which related items could be grouped together as distinct combined variables or factors (Cramer, 2006). This is in line with measurement theory to increase the validity and reliability of factor structures, ensuring (1) uni-dimensionality; (2) alpha reliabilities; and (3) factor loadings, were within acceptable ranges for each sample. Constructs and measures developed were tested by generating a Cronbach alpha value within an acceptable range, which in this case, due to the size of this data and the large number of constructs and measures, a range of .55 to .92 was deemed acceptable. Item inter-correlations identified the least-contributing items to the model and deleted. A second-order confirmatory factor analysis (CFA) was then carried out (Hair et al., 2010) to satisfy requirements of reliability, validity and uni-dimensionality of each of the constructs (Ahire et al., 1996; O'leary-Kelly and Vokurka, 1998).

\section{Composite Variable Constructs and Testing}

Due to the large number of measures and the practicality of running SEM in AMOS, composite variables were constructed for each of the measures required to represent and measure each second-order latent construct supply chain performance differential capability (SCPDC) and supply chain dynamic capability (SCDC) (Grace, and Bollen, 2008). These are set out in Tables 2(a) and Table 2(b) respectively. Composite Model Reliability

Models were created in SEM (which consists of a combination of multiple regression and confirmatory factor analysis) and measured using the Maximum Likelihood Estimates method. This tested reliability and validity of the composite structures for each latent variable construct across the complete data set of respondents, prior to splitting the data to test the whole model against small and large respondents. Constructs were confirmed as adequately representing the model with results are outlined in Table 3(a) for the SCPDC construct reliability and Table 3 (b) for the SCDC construct reliability.

Baseline comparison indices also confirmed the good fit of the model to the data it represents, using Root Mean Residual (RMR) incremental or comparative fit indices such as Goodness of Fit Index (GFI); Adjusted Goodness of Fit Index (AGFI); Norm Fit Index (NFI); Relative Fit Index (RFI); Incremental Fit Index (IFI); Tucker-Lewis Index (TLI); and the Comparative Fit Index (CFI). The most important fit index is the Root Mean-Square Error of Approximation (RMSEA) fit index, which takes into account the error of approximation in the population, and is significant at $\leq 0.05$, with a PCLOSE or $p$ value of $\geq .5$ confirming a very good fitting model against the data. The Akaike Information Criterion (AIC) measure tests for parsimony and model fit with the model recording the lowest indicator confirms the most appropriate model against data.

\section{SEM and Hypothesis Testing - Small verses Large SC Operatives}

Once composite variables were developed and tested for reliability, SEM was used to test the hypotheses against a multi-sample analysis, with the parameters constrained to be the same across two groups - small supply chain (SC) operatives $(\mathrm{N}=292)$ and large supply chain $(\mathrm{SC})$ operatives $(\mathrm{N}=120)$ for both models (Hult et al., 2002). Construct validity of the hypothesized models was tested against the structural model developed, and whether the models differed across the two different groups of respondents (small SC operatives verses large SC operatives) (Joreskog et al., 1999) using Maximum Likelihood Estimation procedure. SEM confirmed the accuracy of the variant models verses the invariant models as the 'best fit' models for both data sets presented (Bryrne, B. M., 1998).

The 'best fit' model to the data in both cases is the variant model with results displayed in Table 4(a) and Table 4(b). As can be seen in Table 4a, only one Baseline Comparison Index - (RFI) recorded a less than desirable score of 0.936, with all others fitting well. Therefore, the SCPDC to ILICU construct is reliable. In Table 4(b), SCDC to ILICU, all Baseline Comparison Indices confirmed a good fitting construct.

Both reliable constructs were then tested against small SC operatives data samples $(\mathrm{N}=292)$ and large SC operatives data samples $(\mathrm{N}=120)$. Table 5(a) represents a comparison of views on SCPDC to ILICU. There were 56 sample moments and 29 parameters measured, with results $\mathrm{X}^{2}=35.252$ with $27 \mathrm{df}$. $\mathrm{X}^{2} / \mathrm{df}=1.306$ with a 
significant $\mathrm{p}$ value $=.475(\geq 0.05)$. Table $5(\mathrm{~b})$ represents a comparison of views on SCDC to ILICU. With respect to SCDC to ILICU there were also 56 sample moments and 35 parameters measured, with results $\mathrm{X}^{2}=20.741$ with $21 \mathrm{df} . \mathrm{X}^{2} / \mathrm{df}=0.988$ with a significant $\mathrm{p}$ value $=.475(\geq 0.05)$.

\section{Discussion and Hypothesis}

\subsection{Supply Chain Performance Differential Capability (SCPDC) Effect}

Results suggest Control $(.626 / \mathrm{p}=\leq .001 ; .573=\leq .001)$, together with Risk $(.420 / \mathrm{p}=\leq .001 ; 391 / \mathrm{p}=\leq .001)$ and Complexity $(.538 / \mathrm{p}=\leq .001 ; .461 / \mathrm{p}=\leq .001)$ were seen as important measures of SCDC for both levels of operatives. However, resources (e-resources) $(.010 / \mathrm{p}=.875 ; .072 / \mathrm{p}=.554)$, was not seen as significant. In terms of SCPDC influencing ILICU, both levels of operatives, found that for a one unit increase in SCPDC there was a $.170 /$ unit $(\mathrm{p}=\leq .001$ ) increase in ILICU. Although there was a .083 standard deviation (sd) increase in ILICU for small operatives, and a .049 standard deviation increase in ILICU for larger operatives. Both levels of operatives agree that SCPDC does influence ILICU and in turn leads to positive financial benefits (FB), operation efficiencies (OE) and growth factors (GF) for the supply chain. Small supply chain operatives scored $1.296 / \mathrm{p}=\leq .001 / \mathrm{sd}=.731(\mathrm{FB}) ; 1.328 / \mathrm{p}=\leq .001 / \mathrm{sd}=.810(\mathrm{OE}) ;$ and $1.000 / \mathrm{sd}=.547(\mathrm{GF})$ respectively. Their larger counterparts scored 1.334/p. $=\leq .001 / \mathrm{sd}=.779(\mathrm{FB}) ; 1.205 / \mathrm{p}=\leq .001 / \mathrm{sd}=.852(\mathrm{OE}) ;$ and $1.000 / \mathrm{sd}=.621(\mathrm{GF})$ respectively.

In terms of measuring standardised total effects (which include standardised direct and indirect effects of SCPDC to ILICU), results suggest for every one unit increase in SCPDC, there will be an equivalent total increase in ILICU of .288 units (small SC operatives) and .221 units (large SC operatives), respectively. This translates, for small and larger operatives respectively, into a .246/unit or .195/unit increase in FB; a .259/unit or .204/unit in OE; and .213/unit or .174/unit in GF. The larger SC operatives believe they derive more direct total benefit from ILICU than small SC operatives, scoring a .883/unit over a $.855 /$ unit in FB; a $.923 /$ unit over a 900/unit increase in OE; and a .788/unit over a 740/unit increase in GF. However, small SC operatives believe SCPDC has a greater influence on ILICU than do their larger counterparts.

Therefore, research findings support Hypotheses 1, that SCPDC influences ILICU, with the exception that both small and large operatives do not believe access to resources (e-resources in this case) is a significant first-order indicator of SCPDC. Hypothesis 3 also has support from both levels of SC operatives, that ILICU can influence financial benefit, operational efficiency, and growth factors. Additionally, Hypothesis 4 is supported which suggests that the size of the supply chain operative acts as a moderator of these relationships.

\subsection{Supply Chain Dynamic Capability (SCDC) Effect}

In relation to measuring SCDC, results suggest both small and large supply chain operatives in this industry believe three of the four measures represented are significant indicators of SCDC. Reconfiguration scored as the most important indicator of SCDC at $.679 / \mathrm{p}=\leq .001 / \mathrm{sd} .456$ for small SC operatives; and $.560=\leq .001 / \mathrm{sd}=.254$ for large SC operatives. Collaboration scored lower for small SC operatives at $.384 / \mathrm{p}=\leq .001 / \mathrm{sd} .169$, than their larger counterparts at $.516 / \mathrm{p}=\leq .001 / \mathrm{sd}=.301$. Adaptability however, scored as the least important indicator of SCDC, for both small and large SC operatives, at $.242 / \mathrm{p}=\leq .001 / \mathrm{sd}=.104$ for small operatives and $.168 / \mathrm{p}=\leq .001 / \mathrm{sd}=.040$ for large operatives. The final indicator, Agility, was the second most important indicator of SCDC for small SC operatives at $.520=\leq .001 / \mathrm{sd}=.337$; but not as important for the large SC operatives at $.423=\leq .001 / \mathrm{sd}=.189$, who believe collaboration to be more important. Both levels of operatives agree that SCDC does influence ILICU and in turn leads to positive financial benefits (FB), operation efficiency $(\mathrm{OE})$ and growth factors (GF) for the supply chain. Small SC operatives scored 1.296/p= $=.001 / \mathrm{sd}=.731$ (FB) ; $1.328 / \mathrm{p}=\leq .001 / \mathrm{sd}=.810(\mathrm{OE}) ;$ and $1.000 / \mathrm{sd}=.547$ (growth) respectively. Their larger counterparts scored 1.334/p. $=\leq .001 / \mathrm{sd}=.779(\mathrm{FB}) ; 1.205 / \mathrm{p}=\leq .001 / \mathrm{sd}=.852(\mathrm{OE}) ;$ and $1.000 / \mathrm{sd}=.621(\mathrm{GF})$ respectively.

Standardized Total Effect measures suggest both small and large SC operatives believe a one-unit increase in SCDC will result in an increase in ILICU, with small operatives scoring a .287 unit increase, and large operatives scoring a .219 unit increase. This is translates into a .248/unit increase in FB; a 256/unit increase in $\mathrm{OE}$ and a .211/unit increase in GF for small SC operatives. For large operatives, they expect a .193/unit increase in FB; a .203/unit increase in (OE); and a .175/unit increase in (GF). In terms of flow-on benefits from SCDC to ILICU, the large SC operatives believe they derive more direct total benefit from ILICU scoring .881 (FB), .925 $(\mathrm{OE})$ and $.790(\mathrm{GF})$ to their small SC operatives who were slightly lower in expectations at .862 (FB), 892 (OE) and .741 (GF). Again, small SC operatives believe SCDC has a greater influence on ILICU and its benefits than do the large SC operatives in this industry.

Therefore, results support Hypotheses 2 suggesting that SCDC has a significant influence on ILICU, subject to Adaptation not being a significant indicator of SCDC by either small or large SC operatives in this industry. 
Results also support Hypothesis 3, that ILICU can influence the financial benefit, operational efficiency, and growth factors of the supply chain. Again, Hypothesis 4 has support, suggesting the size of the SC operative influences the relationship between strategic SC capability (SCDC) and its influence on ILICU any financial benefit, operational efficiencies or growth factors that may result.

\section{Implications and Limitations}

Using SEM to accomplish the aggregated tasks of modelling, testing and gaining some reliability and validity to the outcomes is well represented in the literature (Shook et al., 2004). However, this research method also presents the possibility of a number of limitations (Hair Jr. et al., 2010), and is considered when reporting results. A number of limitations have been identified in the literature that could impact these findings, such as, inadequate reporting of sampling issues, measurement issues, reproducibility issues, equivalent models issues and re-specification issues (Shook et al., 2004). Although we took every effort to address these limitations, we acknowledge that it is not always possible to present all relevant data, relating to the topic of this research, in this study. Such limitations, although they may exist in the context of developing equivalent models and re-specification issues, it should be acknowledged that this study is also limited the nature of its industry-specific data. Alternate findings are therefore possible, subject to the effects of variations in corporate practices occurring within other industries, as compared to the Australian beef industry. In relation to the sample size, it appears robust in terms of the analytical tools applied to examine each strategic supply chain capability and its relationship to industry-led innovation capacity utilization; however, it may be restrictive in terms of a generalizable result. Another consideration in relation to the limitations of the results is the measures used. While the measures were developed from the literature, and appear to reflect the respective latent constructs adequately, they may also be limiting, as other measures may be possible. Regardless, there are still a number of contributions offered by this study.

First, we delineate the higher-order phenomenon: two strategic supply chain capabilities - supply chain performance differential capability and supply chain dynamic capability; and highlight their influence on a strategic supply chain resource - industry-led innovation capacity utilization, and its relationship to supply chain financial benefit, operational efficiency, and growth factors. This study also expands current literature relating to the effect of size on the capacity and capability of operatives from both a supply chain perspective and an innovation perspective. We also provide a catalyst for more inter-disciplinary studies that encapsulate innovation theory, supply chain management theory and strategic management theory. This study provides broader scope to existing lines of inquiry. It highlights and empirically supports the role of two additional strategic supply chain capabilities (Hult and Ketchen Jr, 2001; Hult et al., 2002; Hultet al., 2007; Hult et al., 2006; Ketchen Jr. and Guinipero, 2004). It provides empicial evidence to the nature of innovation capacity existing in small supply chain operatives (Alessandro, 2007; Cakar and Erturk, 2010; Hyland and Beckett, 2004). It also shows how this capacity differs to large operatives (Nieto and Santamaría, 2010; Phillips et al., 2006; Sankaran and Mouly, 2006; Soosay et al., 2008) in this industry. Additionally, the results offer empirical evidence that industry-led innovation capacity utilization does influence supply chain outcomes in relation to financial benefit, operational efficiency, and growth factors in this industry.

For scholars in the areas of performance differentials and dynamic capability, this study, through its theoretical grounding in RBV, broadens these fields to include an understanding of supply chains. It demonstrates the presence of supply chain performance differential capability and supply chain dynamic capability and their relationship to innovation utilization and its benefits. The results suggest, that both small and large operatives agree, that having access to these strategic capabilities can influence their overall supply chain performance, and access to innovation capacity. These results also demonstrate the strategic nature of these capabilities and the moderating influence of the supply chain operative. Both large and small supply chain operatives in this industry agree these capabilities are out of the ordinary (supply chain) routines and operational capabilities that assist to create, extend or modify current resources in order to achieve congruence with their changing business environment (Helfat et al., 2007). They also agree that the indicators, control, risk, and complexity, are sufficient measures of supply chain performance differential capability, while indicators, reconfiguration, collaboration and agility are sufficient to measure supply chain dynamic capability. These strategic supply chain capabilities are obviously seen as part of the innovation utilization process, however, it is possible that supply chain dynamic capability may diminish over time, if not utilised (Eisenhardt and Martin, 2000).

An interesting finding within this research is the resistance of both small and large supply chain operatives to acknowledge e-resources, as an important measure of supply chain performance differential capability. This suggests this traditional agri-business industry, is still questioning the use of e-resources as a differential performance capability tool, capable of creating efficiencies in supply chain management. Even though many 
argue e-resources, have many positive benefits. Especially in relation to managing supply chains, and include, gaining efficiencies in terms of speedy and transparent communications and transactions; improving tracking and traceability; lowering transaction costs; and improving systems and operational integration (Chandrashekar, and Schary, 1999; Koch, 2010). Supply chain academic and practitioner literature often claim e-resources as strategic enabling capability (Devaraj et al., 2007; Hsu and Shih, 2007; Yu et al., 2001). E-resources are seen as platforms for supply chain reconfiguration and collaboration, and also adapting to dynamic changes by providing agility in supply chain response through speed and flexibility (Trienekens et al., 2011). Industry resistance in this instance may come from mismatched levels of information flows, poor synchronization of information, communication, and telecommunications systems, and the inequality of access to high-speed, broadband networks throughout the industry. Often it is the larger operatives in this industry who have the capability to manipulate and manage sophisticated information systems and therefore have a higher level of control of information within the industry. The other interesting finding was that both small and large supply chain operatives did not believe supply chain adaptability was a good indicator or measure of the supply chain dynamic capability. This finding contradicts both dynamic capability literature and supply chain literature (Hallismann et al., 2008; Ketchen Jr. and Hult, 2007; Langdon and Sikora, 2006; Lee, 2006, Tuominen et al., 2003).

\section{Conclusion}

The results of this research confirm empirically that the level of dynamic or reactive capabilities and difference in performance capacity within these supply chain operatives influences the innovation process. These higher-order capabilities, dynamic capability and performance differential capability, assist supply chain operatives to adjust relationships and activities continuously and appropriately, until the innovation capacity is effective and benefits derived. The lack of research into impacts of innovation utilization in a traditional industry contexts, particularly as it relates to the industry supply chain, is also addressed to some degree (Burgess et al., 2006). By addressing the broader industry supply chain focus and treating the supply chain as an 'organization', this study has also supported earlier theory suggesting supply chains would increasingly resemble organizations and should be treated as such (Dunning, 1995). It also supports the strategic approach to supply chain management (Ketchen Jr. and Guinipero, 2004, Ketchen Jr. and Hult, 2007) and strategic nature of supply chain capability (Hult et al., 2002). Finally, it is important to note that innovation utilization is not always positive (Bessant, 2008, Bessant et al., 2005, Carayannis et al., 2003, Danneels, 2008), and can provide uncertainty and discontent to participating supply chain operatives, as it is not an isolated process (Simatupang and Sridharan, 2005).

However, prescribing innovation capacity to any industry, especially electronic business systems, puts pressure on the intra and inter- organizational relationships operating within, and may can pressure on organizational capacity (Ram and Jung, 1991), particularly throughout its supply chain. Even though, widespread use of Internet and Electronic Business Solutions, can contribute to improving the innovativeness and competitiveness of small to medium enterprises (SMEs) (Nieto and Santamaría, 2010; Trienekens et al., 2011). These results could be highlighting the fact that information dissemination is often complex, and contrary to academic literature, reflect a contradiction within this industry. E-resources may be seen as positive in terms of financial benefits, operational efficiencies and growth factors, yet also provide a platform for supply chain discontent, due to an unwillingness to allow greater levels of information transparency. Inequality appears to exist for these supply chain operatives in this industry, in terms of supply chain performance differential capability, supply chain dynamic capability. To some degree, this inequality may be due to the size of the supply chain operative. We recommend further empirical research to extend this work, particularly in other industry sectors, to gain greater insight into the role of strategic capabilities and innovation capacity in supply chains (Hult et al., 2007; Wernerfelt, 1984).

\section{Acknowledgement}

The Cooperative Research Centre for Beef Genetic Technologies (http://www.beefcrc.com.au/) funded this research.

\section{References}

A.B.S. (2001). Small Business in Australia. Retrieved. from http://www.abs.gov.au/AUSSTATS/abs@.nsf/DetailsPage/1321.02001?OpenDocument (downloaded from the Internet 12 June 2010).

Ahire, S. L., Golhar, D. Y., \& Waller, M. A. (1996). Development and validation of TQM implementation constructs. Decision Sciences. 27(1), 25-56. http://dx.doi.org/10.1111/j.1540-5915.1996.tb00842.x. 
Alessandro, M. (2007). The Impact of Absorptive Capacity on SME Innovation. Economics of Innovation and New Technology. 16(8), 653.

Amit, R., \& Schoemaker, P. (1993). Strategic assets and organizational rent. Strategic Management Journal. 14(1), 33-46.

Armstrong, J. S., \& Overton, T. S. (1977). Estimating nonresponse bias in mail surveys. Journal of Marketing Research. 16, 396-400. http://dx.doi.org/310.2307/3150783

Arrow, K. J. (1962). Economic welfare and the allocation of resources for invention. Paper presented at the N.B.E.R. Special Conference Series, Princeton, New Jersey. Princeton University Press.

Assink, M. (2006). Inhibitors of disruptive innovation capability: a conceptual model. European Journal of Innovation Management. 9(2).

Audretsch, D. B., \& Vivarelli, M. (1996). Firms size and R\&D spillovers: evidence from Italy. Small Business Economics. 8, 249-258.

Bagozzi, R. P., \& Fornell, C. (1982). Theoretical concepts, measurements and meaning. In C. Fornell (Ed.), $A$ Second Generation of Multivariate Analysis (pp. 5-23). New York, NY: Praeger Publishers.

Baldridge, J. V., \& Burnham, R. A. (1975). Organizational innovation: Individual, organizational, and environmental impacts. Administrative Science Quarterly, 20, 165-176. http://dx.doi.org/110.2307/2391692.

Barney, J. B. (2003). Resources, capabilities, core competencies, invisible assets and knowledge assets: label proliferation and theory development in the field of strategic management. In C. E. Helfat (Ed.), The SMS Handbook of Organizational Capabilities (pp. 422-426): Blackwell.

Bessant, J. (2008). Dealing with Discontinuous Innovation: The European Experience. International Journal of Technology Management. 42(1-2), 36-50.

Bessant, J., Lamming, R., Noke, H., \& Phillips, W. (2005). Managing innovation beyond the steady state. Technovation. 25(12), 1366-1376.

Bharadwaj, A. S. (2000). A resource-based perspective on information technology capability and firm performance: an empirical investigation. MIS Quarterly. 24(1), 169-196. http://dx.doi.org/110.2307/3250983.

Black, J., \& Boal, K. (1994). Strategic resources: traits, configurations and paths to sustainable competitive advantage. Strategic Management Journal. 15, 131-148. http://dx.doi.org/110.1002/smj.4250151009.

Bowen, F. E. (2002). Does size matter? Business and Society. 41(1), 118-124.

Bryrne, B. M. (1998). Structural Equation Modeling with LISREL, PRELIS, and SIMPLIS. Mahwah, N.J: Lawrence Erlbaum Associates.

Buhalis, D. (1998). Strategic use of information technologies in the tourism industry. Tourism Management. 19(5), 409-421. http://dx.doi.410.1016/S0261-5177(1098)00038-00037.

Burgess, K. (2007). The role of the social factors in generating innovation within mature industry supply chains - a case study. RMIT Melbourne.

Burgess, K., Singh, P. J., \& Koroglu, R. (2006). Supply chain management: a structured literature review and implications for future research. International Journal of Operations and Production Management. 26, $703-729$. http://dx.doi.org/710.1504/IJSOM.2006.009860.

Cakar, N. D., \& Erturk, A. (2010). Comparing innovation capability of small and medium-sized enterprises: examining the effects of organizational culture and empowerment. Journal of Small Business Management. 48(3), 325-359.

Carayannis, E. G., Gonzalez, E., \& Wetter, J. (2003). The nature and dynamics of discontinuous and disruptive innovations from a learning and knowledge management perspective. In L. V. LShavinina (Ed.), The International Handbook on Innovation (pp. 115-138).

Chandler, J., A.D. (1990). Scale and Scope: The Dynamics of Industrial Capitalism. Cambridge, MA: Harvard University Press, Belknap Press.

Chandrashekar, A. a. S., P. B. (1999). Towards the virtual supply chain: The convergence of IT and organization. The International Journal of Logistics Management. 10(2), 27-39.

Chang, H.-H., Chen, C.-H., \& Su, C.-H. (2008). Developing supply chain dynamic capability to realize the value of inter-organizational systems. Paper presented at the PACIS 2008 - Pacific Asia Conference on Information 
Systems - Leveraging ICT for Resilient Organizations and Sustainable Growth in the Asia Pacific Region Session 4A: Organizational Agility and Firm Performance. .

Churchill, G. A. (1979). A paradigm for developing better measures of marketing construct. Journal of Marketing Research. 16, 64-72. http://dx.doi.org/10.2307/3150876.

Cohen, W. M., \& Klepper, S. (1996). Firm size and the nature of innovation within industries: the case of process and product R\&D. Review of Economics and Statistics. 78(2), 232-243. http://dx.doi.org/210.2307/2109925.

Collis, D. J. (1994). Research Note: How Valuable are Organizational Capabilities? Strategic Management Journal, 15(S1), 143-152. http://dx.doi.org/110.1002/smj.4250150910.

Cox, A. (1997). Business Success: A Way of Thinking About Strategy, Critical Supply Chain Assets and Operational Best Practice. Boston: Earlsgate Press.

Cramer, D. (2006). Advanced Quantitative Data Analysis. Philadelphia, PA: Open University Press.

Crowston, K., \& Kammerer, E. E. (1998). Coordination and collective mind in software requirements development. IBM Systems Journal. 37(2), 227-245. http://dx.doi.org/210.1147/sj.1372.0227.

Damanpour, F. (1992). Organizational size and innovation. Organization Studies. 13(3), 375-402. http://dx.doi.org/310.1177/017084069201300304.

Danneels, E. (2008). Organizational antecedents of second-order competences. Strategic Management Journal. 29(5), 519-543. http://dx.doi.org/510.1002/smj.1684.

Dekker, H. C. (2004). Control of inter-organizational relationships: evidence on appropriation concerns and coordination requirements. Accounting, Organizations and Society. 29, 27-49.

Devaraj, S., Krajewski, L., \& Wei, J. C. (2007). Impact of eBusiness technologies on operational performance: The role of production information integration in the supply chain. Journal of Operations Management. 25(6), 1199-1216. http://dx.doi.org/1110.1016/j.jom.2007.1101.1002.

Dillman, D. A. (1978). Mail and Telephone Surveys: The Total Design Method. New York, NY: Wiley.

Dunning, J. H. (1995). Reappraising the eclectic paradigm in an age of alliance capitalism. Journal of International Business Studies. 26, 461-492. http://dx.doi.org/410.1057/palgrave.jibs.8490183.

Dyer, J. H., \& Singh, H. (1998). The relational view: cooperative strategy and sources of interorganizational competitive advantage. Academy of Management Review. 23(4), 660-679. http://dx.doi.org/610.5465/AMR.1998.1255632.

Eisenhardt, K. M., \& Martin, J. A. (2000). Dynamic Capabilities: What Are They? Strategic Management Journal. 21(10/11), $1105-1121$. http://dx.doi.org/1110.1002/1097-0266(200010/200011)200021:200010/200011<201105::AID-SMJ200133>200 013.200010.CO;200012-E.

Evangelia, D. F. (2006). Transforming the supply chain. Journal of Manufacturing Technology Management. 17(6), 848.

Fennell, M. L. (1984). Synergy, influence, and information in the adoption of administrative innovations. Academy of Management Journal. 27, 113-129. http://dx.doi.org/110.2307/255960

Galunic, D. C., \& Rodan, S. (1998). Resource Recombinations in the Firm: Knowledge Structures and the Potential for Schumpeterian Innovation. Strategic Management. 19(12), 1193-1201. http://dx.doi.org/1110.1002/(SICI)1097-0266(1998120)1998119:1998112<1991193::AID-SMJ1998125>199812 3.1998120.CO;1998122-F.

Godfrey, P., C. , \& Hill, C., W. L. . (1995). The problem of unobservables in strategic management research. Strategic Management Journal. 16(7), 519-533. http://dx.doi.org/510.1002/smj.4250160703.

Goode, S., \& Gregor, S. (2009). Rethinking organisational size: Meaning, Measurement and Redevelopment. European Journal of Information Systems. 18(1), 4-25. http://dx.doi.org/10.1057/ejis.2009.1052.

Grace, J., \& Bollen, K. (2008). Representing general theoretical concepts in structural equation models: the role of composite variables. Environmental and Ecological Statistics. 15(2), 191-213. http://dx.doi.org/110.1007/s10651-10007-10047-10657. 
Grant, R. M. (1996). Toward a knowledge-based theory of the firm. Strategic Management Journal. 17, 109-122.

Hair, J., F., Black, W. C., Babin, B. J., \& Anderson, R. E. (2010). Multivariate Data Analysis: A Global Perspective (7th ed.). Upper Saddle River, NJ: Pearson Prentice Hall.

Hair Jnr, J., F., Black, W. C., Babin, B. J., \& Anderson, R. E. (2010). Multivariate Data Analysis: A Global Perspective (7th ed.). Upper Saddle River, NJ: Pearson Prentice Hall.

Hair Jr., J. F., Black, W. C., ', Babin, B. J., \& Anderson, R. E. (2010). Multivariate Data Analysis: A Global Perspective (7th ed.). New York, NY: Pearson.

Hallismann, M., Grapp, J., \& Li, Y. (2008). Strategic adaptivity in global supply chains - Competitive advantage by autonomous cooperation. International Journal of Production Economics. 114(1), 14-26.

Hausdorf, P. A., \& Duncan, D. (2004). Firm size and internet recruiting in Canada: A preliminary investigtion. Journal of Small Business Management. 42(3), 325-334.

Helfat, C. E., Finkelstein, S., Mitchell, W., Peteraf, M., Singh, H., Teece, D., ., et al. (2007). Dynamic Capabilities: Understanding Strategic Change in Organizations. Malden, MA: Blackwell.

Helfat, C. E., \& Peteraf, M. A. (2009). Understanding dynamic capabilities: progress along a developmental path. Strategic Organization. 7(1), 91-102. http://dx.doi.org/110.1177/1476127008100133.

Hitt, M. A., Dacin, M. T., Levitas, E., Arregle, J.-L., \& Borza, A. (2000). Partner Selection in Emerging and Developed Market Contexts: Resource-Based and Organizational Learning Perspectives. The Academy of Management Journal. 43(3), 449-467. http://dx.doi.org/410.2307/1556404.

Hopwood, A. (1996). Looking across rather than up and down: on the need to explore the lateral processing of information. Accounting, Organizations and Society. 21, 589-590.

Hoyle, R. (1995). Structural Equation Modeling. Thousand Oaks, CA: Sage Publications.

Hsu, H. Y. S., \& Shih, S. C. (2007). Strategic Alliances of Information Technology Among Supply Chain Channel Members. In Supply Chain Management: Issues in the New Era of Collaboration and Competition. Hershey, PA, USA: Idea Group Publishing.

Hult, G., Tomas, M., Ketchen Jr, D. J., Adams, G. L., \& Mena, J. A. (2008). Supply Chain Orientation and Balanced Scorecard Performance. Journal of Managerial Issues. 20(4), 526-544.

Hult, G. T. M., Ketchen, D. J., \& Arrfelt, M. (2007). Strategic supply chain management: Improving performance through a culture of competitiveness and knowledge development. Strategic Management Journal. 28(10), 1035-1052. http://dx.doi.org/1010.1002/smj.1627.

Hult, G. T. M., Ketchen, D. J., \& Nichols, E. L. (2002). An examination of cultural competitiveness and order fulfilment cycle time within supply chains. Academy of Management Journal. 45(3), 577-586. http://dx.doi.org/510.2307/3069382.

Hult, G. T. M., Ketchen, J. D. J., Cavusgil, S. T., \& Calantone, R. J. (2006). Knowledge as a strategic resource in supply chains. Journal of Operations Management, 24(5), 458-475.

Hult, G. T. M., \& Ketchen Jr, D. J. (2001). Does market orientation matter? A test of the relationship between positional advantage and performance. Strategic Management Journal. 22(9), 899-906. http://dx.doi.org/810.1002/smj.1197.

Hult, G. T. M., Ketchen Jr, D. J., \& Slater, S. F. (2004). Information processing, knowledge development and strategic supply chain performance. Academy of Management Journal. 47(2), 241-253. http://dx.doi.org/210.2307/20159575.

Hyland, P., W., , \& Beckett, R., C. . (2004). Innovation and enhancement of enterprise capabilities. A survey of assessment approaches. The International Journal of Technology Management \& Sustainable Development. 3(1), 35.

Jie, F., Parton, K. A., Jenkins, R., \& Cox, R. (2007). Supply chain performance indicators for Australian Beef Enterprises: an empirical approach. Paper presented at the Proceedings of the 21st ANZAM (Australian New Zealand Academy of Management) Conference. from http://www.uow.edu.au/sbs/aboutus/staff/ferryjie/index.htm.

Joreskog, K. G., Sorbom, D., Du Toit, S., \& Du Toit, M. (1999). LISREL 8: New statistical features. Chicago: Scientific Software International. 
Kaufman, A., Wood, C. H., \& Theyel, G. (2000). Collaboration and technology linkages: a strategic supplier typology. Strategic Management Journal. 21(6), 649-663.

Ketchen, D. J., \& Guinipero, L. (2004). The intersection of strategic management and supply chain management. Industrial Marketing Management. 33, 51-56. http://dx.doi.org/10.1016/j.indmarman.2003.1008.1010.

Ketchen, D. J., \& Hult, G. T. M. (2007). Bridging organization theory and supply chain management: The case of best value supply chains. Journal of Operations Management. 25(2), 573. http://dx.doi.org/510.1016/j.jom.2006.1005.1010.

Ketchen Jr, D. J. (2003). Introduction: Raymond E. Miles and Charles C. Snow's Organizational Strategy, Structure, and Process. Academy of Management Executive. 17(4), 95-96. http://dx.doi.org/10.5465/AME.2003.11851865.

Ketchen Jr, D. J., Hult, G. T. M., \& Slater, S. F. (2007). Toward greater understanding of market orientation and the resource-based view. Strategic Management Journal. 28(9), 961-964. http://dx.doi.org/910.1002/smj.1620.

Koch, H. (2010). Developing dynamic capabilities in electronic marketplaces: A cross-case study. The Journal of Strategic Information Systems. 19(1), 28-38. http://dx.doi.org/10.1016/j.jsis.2010.1002.1001.

Kogut, B., \& Zander, U. (1992). Knowledge of the Firm, Combinative Capabilities, and the Replication of Technology. Organization Science. 3(3), 383-397. http://dx.doi.org/310.1287/orsc.1283.1283.1383.

Kotey, B., \& Folker, C. (2007). Employee training in SMEs: effect of size and firm type - family and nonfamily. Journal of Small Business Management. 45(2), 214-238.

Krause, D., R. , Handfield, R., B., \& Tyler, B., B. . (2007). The relationships between supplier development, commitment, social capital accumulation and performance improvement. Journal of Operations Management. 25(2), 528-545. http://dx.doi.org/510.1016/j.jom.2006.1005.1007.

Lambert, D. M., Emmelhainz, M. A., \& Gardner, J. T. (1996). Developing and Implementing Supply Chain Partnerships. The International Journal of Logistis Management. 7(2), 1-17. http://dx.doi.org/10.1108/09574099610805485.

Lamming, R., Caldwell, N., \& Phillips, W. (2006). A Conceptual Model of Value-Transparency in Supply. European Management Journal. 24(2-3), 206-213. http://dx.doi.org/210.1016/j.emj.2006.1003.1010.

Langdon, C. S., \& Sikora, R. T. (2006). Conceptualizing Co-ordination and Competition in Supply Chains as Complex Adaptive System. Information Systems and e-Business Management. 4(1), 71-81.

Lee, B., Kim, P., Hong, K., \& Lee, I. (2010). Evaluating antecedents and consequences of supply chain activities: an integrative perspective. International Journal of Production Research. 48(3), 657. http://dx.doi.org/610.1080/00207540802425377.

Lee, H. L. (2004). The triple A supply chain. Harvard Business Review. 82(10), 102-112.

Lee, H. L. (2006). The Triple-A Supply Chain. In H. B. Review (Ed.), Harvard Business Review on Supply Chain Management (pp. 1). Boston: Harvard Business School Press.

Mabert, V. A., Soni, A., \& Venkataramanan, M. A. (2003). The impact of organization size on enterprise resource planning (ERP) implementations in the US manufacturing sector. Omega. 562, 111-126. http://dx.doi.org/110.1016/S0305-0483(1003)00022-00027.

Mabert, V. A., \& Venkataramanan, M. A. (1998). Special research focus on supply chain linkages: Challenges for design and management in the 21st century. Decision Sciences. 29(3), 537. http://dx.doi.org/510.1111/j.1540-5915.1998.tb01353.x.

Mansfield, E. (1968). Industrial research and technological innovation. New York: Norton.

Maruyama, G. (1998). Basics of Structural Equation Modeling. Thousand Oaks, CA: Sage Publications.

Menon, A. G. (2008). Revisiting dynamic capability. IIMB Management Review. 20(1), 22-33.

Nelson, R., \& Winter, S. (1982). An Evolutionary Theory of Economic Change. Cambridge: Cambridge University Press.

Newman, W., Hanna, M., Gattiker, T., \& Huang, X. (2009). Charting Supply Chain Management Integration and Initiatives: A Framework to Guide Implementation. American Journal of Business. 24(1), 19. http://dx.doi.org/10.1108/19355181200900002. 
Nieto, M. J., \& Santamaria, L. (2010). Technological collaboration: bridging the innovation gap between small and large firms. Journal of Small Business Management. 48(1), 44-69.

Nieto, M. J., \& Santamaría, L. (2010). Technological collaboration: bridging the innovation gap between small and large firms. Journal of Small Business Management. 48(1), 44-69. http://dx.doi.org/10.1111/j.1540-1627X.2009.00286.x.

Nonaka, I., \& Takeuchi, H. (1995). Knowledge-creating Company. Oxford, UK: Oxford University Press.

O'Leary-Kelly, S. W., \& Vokurka, R. J. (1998). The empirical assessment of construct validity. Journal of Operations Management. 16, 387-405. http://dx.doi.org/310.1016/S0272-6963(1098)00020-00025.

Paterson, I. (2006). Trust and technology adoption in Australian agribusiness supply chains: a gap analysis approach. University of Southern Queensland, Toowoomba, Qld, Aus.

Pavlou, P. O. A., \& Sawy, E. L. (2006). Decomposing and leveraging dynamic capabilities. Anderson Graduate School of Management, University of California.

Peteraf, M. A. (1993). The cornerstones of competitive advantage: a resource-based view. Strategic Management Journal. 14(3), 179-191. http://dx.doi.org/110.1002/smj.4250140303.

Phillips, W., Lamming, R., Bessant, J., \& Noke, H. (2006). Discontinuous innovation and supply relationships: strategic dalliances. $R \& D$ Management. 36(4), 451. http://dx.doi.org/410.1111/j.1467-9310.2006.00442.x.

Podsakoff, P., \& Organ, D. W. (1986). Self-reports in organizational research: problems and prospects. Journal of Management. 12(4), 531-543. http://dx.doi.org/510.1177/014920638601200408.

Prieto, I., \& Easterby-Smith, M. P. V. (2006). Dynamic capabilities and the role of organizational knowledge: an exploration. European Journal of Information Systems. 15(5), 500-510. http://dx.doi.org/510.1057/palgrave.ejis.3000642.

Ram, S., \& Jung, H.-S. (1991). Forced adoption of innovations in organizations: consequences and implications. Journal of Product Innovation Management. 8(2), 117-126. http://dx.doi.org/110.1111/1540-5885.820117.

Robertson, T. S., \& Gatignon, H. (1987). The diffusion of high technology innovations: A marketing perspective. In J. M. P. a. A. B. (eds.) (Ed.), New technology as Organizational Innovation (pp. 179-196). Cambridge, MA: Ballinger.

Rogers, M. (2004). Networks, firm size and innovation. Small Business Economics. 22, 141-153.

Rothaermel, F., T. . (2001). Incumbent's advantage through exploiting complementary assets via interfirm cooperation. Strategic Management Journal. 22(6-7), 687-699. http://dx.doi.org/610.1002/smj.1180.

Rumelt, R. P. (1987). Strategy, economic theory and entrepreneurship. In The Competitive Challenge. Cambridge: Ballinger Books.

Sabath, R., \& Fontanella, J. (2002). The Unfulfilled Promise Of Supply Chain Collaboration. Supply Chain Management Review, 6(4), 24-29.

Sankaran, J. K., \& Mouly, V. S. (2006). Value Chain Innovation in Aquaculture: Insights from a New Zealand Case Study. R\&D Management. 36(4), 387-401. http://dx.doi.org/310.1111/j.1467-9310.2006.00441.x.

Saren, M. (1987). The role of strategy in technological innovation. In I. L. Mangham \& (ed.) (Eds.), $A$ Re-assessment in Organization Analysis and Development (pp. 125-165). Chichester: Wiley.

Schumacker, R., \& Lomax, R. (1996). A Beginner's Guide to Structural Equation Modeling. New Jersey: Lawrence Erlbaum and Associates.

Shook, C. L., Ketchen Jr, D. J., Hult, G. T. M., \& Kacmar, K. M. (2004). An assessment of the use of Structural Equation Modeling in Strategic Management research. Strategic Management Journal. 25(4), 397-404.

Simatupang, T. M., \& Sridharan, R. (2005). Supply Chain Discontent. Business Process Management Journal. 11(4), 349-369.

Soosay, C. A., Hyland, P. W., \& Ferrer, M. (2008). Supply chain collaboration: capabilities for continuous innovation. Supply Chain Management. 13(2), 160-169.

Srivastava, R. K., Fahey, L., \& Christensen, H. K. (2001). The resource-based view and marketing: the role of market-based assets in gaining competitive advantage. Journal of Management. 27, 777-802.

Stank, T. P., \& Goldsby, T. F. (2000). A framework for transportation decision making in an integrated supply chain. Supply Chain Management: An International Journal. 5(2), 71-77. 
Stevenson, M., \& Spring, M. (2007). Flexibility from a supply chain perspective: definition and review. International Journal of Operations \& Production Management. 27(7), 685.

Stoelhorst, J. W., \& van Raaij, E. M. (2004). On explaining performance differentials: Marketing and the managerial theory fo the firm. Journal of Business Research. 57, 462-477. http://www.doi:410.1016/S0148-2963(1002)00313-00312.

Storer, M., \& Hyland, P. (2010). Reconfiguration or Innovation in Supply Chains? International Journal of Technology Management, Special Edition (Accepted - Awaiting publication). 1 - 20.

Tang, C. S. (2006a). Perspectives in supply chain risk management. International Journal of Production Economics. 103(2), 451-488. http://dx.doi.org/410.1016/j.ijpe.2005.1012.1006.

Tang, C. S. (2006b). Robust strategies for mitigating supply chain disruptions. International Journal of Logistics: Research and Applications. 9(1), 33-45. http://dx.doi.org/10.1080/13675560500405584.

Teece, D. J., Pisano, G., \& Shuen, A. (1997a). Dynamic Capabilities and Strategic Management. Strategic Management Journal. 18(7), 509-533.

Teece, D. J., Pisano, G., \& Shuen, A. (1997b). Dynamic capabilities and strategic management. Strategic Management Journal. 18(7), 509-533. http://dx.doi.org/510.1002/(SICI)1097-0266(199708)199718:199707<199509::AID-SMJ199882>199703.19970 $0 . \mathrm{CO} ; 199702-\mathrm{Z}$.

Trienekens, J. H., Wognum, P. M., Beulens, A. J. M., \& van der Vorst, J. G. A. J. (2011). Transparency in complex dynamic food supply chains. Advanced Engineering Informatics, In Print(0) . http://dx.doi.org/10.1016/j.aei.2011.1007.1007.

Utterback, J. M. (1982). Innovation in industry and the diffusion of technology. In M. L. T. a. W. L. M. (eds.) (Ed.), Readings in the management of innovation (pp. 29-41). Boston: Pitman.

van Hoek, R. I., Harrison, A. and Christopher, M. (2001). Measuring agile capabilities in the supply chain. International Journal of Operations \& Production Management. 21(1), 126-148.

Wang, N., Zhang, N., \& Wang, M. (2006). Wireless sensors in agriculture and food industry-Recent development and future perspective. Computers and Electronics in Agriculture. 50, 1-14. http://dx.doi.org/10.1016/j.compag.2005.1009.1003.

Wernerfelt, B. (1984). A Resource-Based View of the Firm. Strategic Management Journal. 5(2), 171. $\mathrm{http}: / / \mathrm{dx}$. doi.org/110.1002/smj.4250050207.

Williamson, O. E. (1999). Strategy Research: Governance and Competence Perspectives. Strategic Management Journal. 20(12), 1087-1108.

Wilson, T., \& Clarke, W. R. (1998). Food safety and traceability in the agricultural supply chain: using the Internet to deliver traceability. Supply Chain Management. 3(3), 127-133.

Wisner, J. D. (2003). A structural equation model of supply chain management strategies and firm performance. Journal of Business Logistics. 24. http://dx.doi.org/10.1002/j.2158-1592.2003.tb00030.x(1)

Wu, F., Yeniyurt, S., Kim, D., \& Cavusgil, S. T. (2006). The impact of information technology on supply chain capabilities and firm performance: A resource-based view. Industrial Marketing Management. 35, 493-504. http://dx.doi.org/410.1016/j.indmarman.2005.1005.1003.

Yu, Z., Yan, H. and Cheng T.C.E. (2001). Benefits of information sharing with supply chain partnerships. Industrial Management \& Data Systems. 101(3), 141-121.

Zollo, M., \& Winter, S. G. (2002). Deliberate learning and the evolution of dynamic capabilities. Organization Science. 13, 339-351.

Zott, C. (2003). Dynamic Capabilities and the Emergence of Intra-Industry Differential Firm Performance: Insights from a Simulation Study. Strategic Management Journal. 24(1), 97-125. http://dx.doi.org/110.1002/smj.1288 
Table 1. Industry Survey Response Characteristics

\begin{tabular}{ll}
\hline \multicolumn{1}{c}{ Key Supply Chain Function/Role } & $\mathbf{\%}$ \\
\hline Production & 30 \\
Live and Cold Chain Logistics and Warehousing & 10 \\
Professional \& Other Services & 17 \\
Processing / Manufacturing & 28 \\
Sales & 15 \\
Chief Executive Officers & 21 \\
Supply Chain or Procurement Managers & 17 \\
Business Owners / Managing Directors & 62 \\
\hline
\end{tabular}

Table 2(a). SCPDC - Construct of Composite Variables

\begin{tabular}{|c|c|c|c|c|c|c|}
\hline $\begin{array}{l}\text { Composite } \\
\text { Latent Variable }\end{array}$ & Measure & $\begin{array}{l}\text { Cronbach } \\
\text { Alpha }\end{array}$ & $\begin{array}{l}\text { St.dev of } \\
\text { Composite } \\
\left(\mathbf{s}_{\mathbf{x}}\right)\end{array}$ & 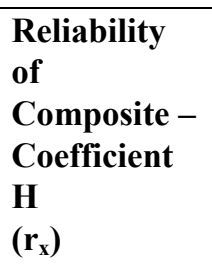 & $\begin{array}{l}\text { Factor } \\
\text { Loading } \\
(\mathbf{l}) \\
\left(\mathbf{s}_{\mathbf{x}} *{ }^{*} \mathbf{O r}_{\mathbf{x}}\right)\end{array}$ & $\begin{array}{l}\text { Error } \\
\text { Variance (q) } \\
\left(\mathbf{s}_{\mathbf{x}}^{2}\left[1-r_{x}\right]\right)\end{array}$ \\
\hline Control_Comp & $\begin{array}{l}\text { Control } \\
\text { Q1-to Q5 }\end{array}$ & 0.9150 & 0.8857 & 0.7740 & 0.7792 & 0.1773 \\
\hline Resources_Comp & $\begin{array}{l}\text { Resource Q1 } \\
\text { to Q4 }\end{array}$ & 0.9630 & 0.9469 & 0.8980 & 0.8973 & 0.0914 \\
\hline Risk_Comp & $\begin{array}{l}\text { Risk Q1 to } \\
\text { Q4 }\end{array}$ & 0.9360 & 0.8651 & 0.7570 & 0.7527 & 0.1819 \\
\hline Complexity_Comp & $\begin{array}{l}\text { ComplexQ1 } \\
\text { to Q4 }\end{array}$ & 0.9550 & 0.9420 & 0.8800 & 0.8837 & 0.1065 \\
\hline
\end{tabular}

Table 2(b). SCDC - Construct of Composite Variables

\begin{tabular}{|c|c|c|c|c|c|c|}
\hline $\begin{array}{l}\text { Composite } \\
\text { Latent Variable }\end{array}$ & Measure & $\begin{array}{l}\text { Cronbach } \\
\text { Alpha }\end{array}$ & $\begin{array}{l}\text { St.dev of } \\
\text { Composite } \\
\left(s_{x}\right)\end{array}$ & $\begin{array}{l}\text { Reliability of } \\
\text { Composite - } \\
\text { Coefficient } \mathrm{H} \\
\left(\mathbf{r}_{\mathrm{x}}\right) \\
\end{array}$ & $\begin{array}{l}\text { Factor } \\
\text { Loading } \\
\text { (l) }\left(s_{x} * \ddot{O} r_{x}\right)\end{array}$ & $\begin{array}{l}\text { Error } \\
\text { Variance } \\
(\mathbf{q}) \\
\left(\mathbf{s}_{x}{ }^{2}\left[1-r_{x}\right]\right)\end{array}$ \\
\hline Reconfigure_Comp & $\begin{array}{l}\text { Reconfig } \\
\text { Q1-Q5 } \\
\text { Collab }\end{array}$ & 0.8410 & 1.0512 & 0.8510 & 0.9697 & 0.1646 \\
\hline Collaboration_Comp & $\begin{array}{l}\text { Q1-Q13 } \\
\text { Adapt }\end{array}$ & 0.8333 & 0.9389 & 0.8790 & 0.8803 & 0.1067 \\
\hline Adaptability_Comp & $\begin{array}{l}\text { Q1-Q17 } \\
\text { Agility }\end{array}$ & 0.8600 & 0.7800 & 0.8340 & 0.7123 & 0.1010 \\
\hline Agility_Comp & Q1-Q4 & 0.9270 & 0.9198 & 0.8430 & 0.8446 & 0.1328 \\
\hline
\end{tabular}


Table 3 (a). SCPDC - Composite Measurement Model Reliability

\begin{tabular}{|c|c|c|c|}
\hline $\begin{array}{l}\text { Default Model - Composite } \\
\text { Constructs }\end{array}$ & $\begin{array}{l}\text { Parameters } \\
\text { Estimated }\end{array}$ & $\begin{array}{l}\text { Initial Fit Statistics = } \\
\text { ChiSquare/Degree of } \\
\text { Freedom/Significance } \\
\text { And Parsimony - AIC }\end{array}$ & $\begin{array}{l}\text { Baseline Comparison } \\
\text { Indices confirming a good } \\
\text { fitting model }\end{array}$ \\
\hline $\begin{array}{l}\text { Control (5 measures) } \\
\text { Resources ( } 4 \text { measures) } \\
\text { Risk ( } 4 \text { measures) } \\
\text { Complexity ( } 6 \text { measures) }\end{array}$ & 10 & $\begin{array}{l}.236 / 2 \mathrm{df}=.118 \text { ( } \mathrm{p}=.889 \\
\text { which indicates a good fit } \\
\text { as } \mathrm{p} \geq 0.05 \text { ) } \\
\text { AIC measure for } \\
\text { parsimony and model fit } \\
\text { for the default model }= \\
0.040 \text { against the saturated } \\
\text { model }=0.049 \text { and an } \\
\text { independence model } \\
=0.310 . \text { Therefore the } \\
\text { Default model is the best } \\
\text { fitting model. }\end{array}$ & $\begin{array}{l}\text { RMR }=.005(\leq 0.05) \\
\text { GFI }=1.000(\geq 0.95) \\
\text { AGFI }=.999(\geq 0.95) \\
\text { NFI }=.998(\geq 0.95) \\
\text { RFI }=.994(\geq 0.95) \\
\mathrm{IFI}=1.015(\geq 0.95) \\
\mathrm{TLI}=1.047(\geq 0.95) \\
\mathrm{CFI}=1.000(\geq 0.95) \\
\mathrm{RMSEA}=0.000(\leq 0.05) \\
\mathrm{PCLOSE}=.958(\geq 0.5)\end{array}$ \\
\hline
\end{tabular}

Table 3(b). SCDC Composite Measurement Model Reliability

\begin{tabular}{|c|c|c|c|}
\hline $\begin{array}{l}\text { Default Model - Composite } \\
\text { Constructs }\end{array}$ & $\begin{array}{l}\text { Parameters } \\
\text { Estimated }\end{array}$ & $\begin{array}{l}\text { Initial Fit Statistics = } \\
\text { ChiSquare/Degree of } \\
\text { Freedom/Significance } \\
\text { And Parsimony - AIC }\end{array}$ & $\begin{array}{l}\text { Baseline Comparison } \\
\text { Indices confirming a good } \\
\text { fitting model }\end{array}$ \\
\hline $\begin{array}{l}\text { Reconfiguration ( } 5 \text { measures) } \\
\text { Collaboration ( } 13 \text { measures) } \\
\text { Adaptability ( } 17 \text { measures) } \\
\text { Agility (4 measures) }\end{array}$ & 10 & $\begin{array}{l}\text { AIC measure for } \\
\text { parsimony and model fit } \\
\text { for the default model }= \\
16.736 \text { against the } \\
\text { saturated model }=20.000 \\
\text { and an independence } \\
\text { model }=122.984 \text {. } \\
\text { Therefore the Default } \\
\text { model is the best fitting } \\
\text { model. }\end{array}$ & $\begin{array}{l}\mathrm{RMR}=.019(\leq 0.05) \\
\mathrm{GFI}=0.997(\geq 0.95) \\
\mathrm{AGFI}=.989(\geq 0.95) \\
\mathrm{NFI}=.976(\geq 0.95) \\
\mathrm{RFI}=.952(\geq 0.95) \\
\mathrm{IFI}=1.005(\geq 0.95) \\
\mathrm{TLI}=1.005(\geq 0.95) \\
\mathrm{CFI}=1.000(\geq 0.95) \\
\mathrm{RMSEA}=0.000(\leq 0.05) \\
\mathrm{PCLOSE}=.766(\geq 0.5)\end{array}$ \\
\hline
\end{tabular}


Table 4(a). SCPDC Construct to ILICU Construct

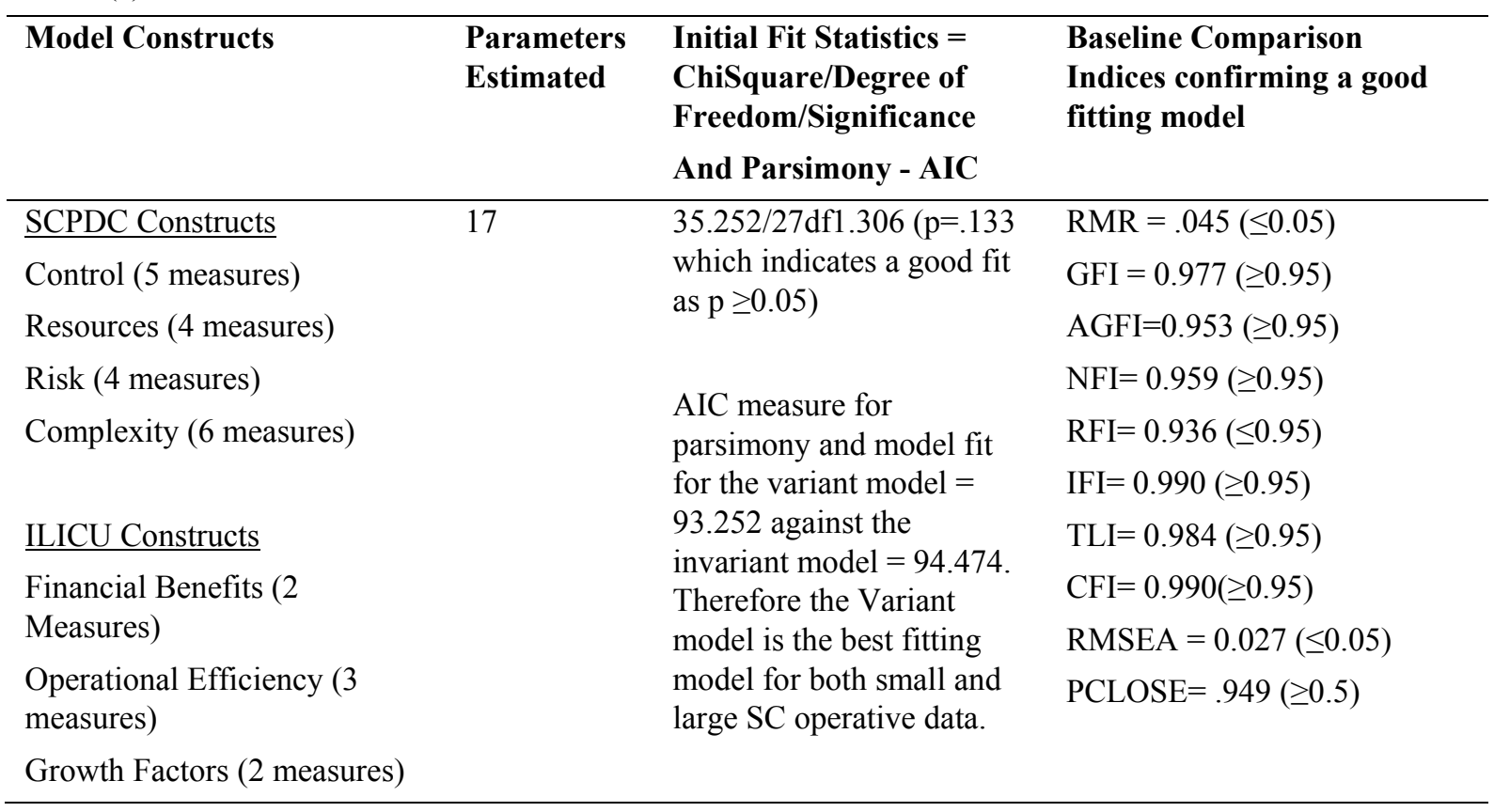

Table 4(b). SCDC Construct to ILICU Construct

\begin{tabular}{|c|c|c|c|}
\hline Model Constructs & $\begin{array}{l}\text { Parameters } \\
\text { Estimated }\end{array}$ & $\begin{array}{l}\text { ChiSquare/Degree of } \\
\text { Freedom/Significance -= } \\
\text { Fit Statistics }\end{array}$ & $\begin{array}{l}\text { Baseline Comparison } \\
\text { Indices confirming a } \\
\text { good fitting model }\end{array}$ \\
\hline SCDC Constructs & \multirow[t]{10}{*}{56} & \multirow{3}{*}{$\begin{array}{l}20.741 / 21 \mathrm{~d} / \mathrm{f}=.988(\mathrm{p}=.475 \\
\text { which indicates a good fit as } \\
\mathrm{p} \geq 0.05)\end{array}$} & $\mathrm{RMR}=.035(\leq 0.05)$ \\
\hline Reconfiguration (5 measures) & & & $\mathrm{GFI}=0.986(\geq 0.95)$ \\
\hline Collaboration (13 measures) & & & $\mathrm{AGFI}=.962(\geq 0.95)$ \\
\hline Adaptability (17 measures) & & \multirow{7}{*}{$\begin{array}{l}\text { AIC measure for parsimony } \\
\text { and model fit for the variant } \\
\text { model }=90.741 \text { against the } \\
\text { invariant model = } 92.315 \text {. } \\
\text { Therefore the Variant model } \\
\text { is the best fitting model for } \\
\text { both small and large SC } \\
\text { operative data. }\end{array}$} & $\mathrm{NFI}=.977(\geq 0.95)$ \\
\hline Agility (4 measures) & & & $\mathrm{RFI}=.953(\geq 0.95)$ \\
\hline & & & $\mathrm{IFI}=1.000(\geq 0.95)$ \\
\hline ILICU Constructs & & & $\mathrm{TLI}=1.001(\geq 0.95)$ \\
\hline Financial Benefits (2 Measures) & & & $\mathrm{CFI}=1.000(\geq 0.95)$ \\
\hline Operational Efficiency (3 & & & RMSEA $=0.000(\leq 0.05)$ \\
\hline me & & & PCLOSE $=.988(\geq 0.5)$ \\
\hline Growth Factors ( 2 measures) & & & \\
\hline
\end{tabular}


Table 5(a). SEM Results - Small SC Operatives verses Large Operatives

\begin{tabular}{|c|c|c|c|c|c|c|c|c|c|}
\hline Path & Est & $\mathbf{t}$ & $\mathbf{p}$ & Var & $\mathbf{t}$ & $\mathbf{p}$ & $\begin{array}{l}\text { Std } \\
\text { Est }\end{array}$ & $\begin{array}{l}\text { Sq. } \\
\text { MC }\end{array}$ & $\begin{array}{l}\text { Std } \\
\text { Total } \\
\text { Effects }\end{array}$ \\
\hline \multicolumn{10}{|c|}{ SMALL SC OPERATIVES } \\
\hline SCPDC to ILICU & .170 & 4.117 & $* * *$ & .319 & 6.874 & $* * *$ & .288 & .083 & .288 \\
\hline SCPDC to Comp_Control & .626 & 9.143 & $* * *$ & .375 & 5.181 & $* * *$ & .715 & .511 & .715 \\
\hline $\begin{array}{l}\text { SCPDC to } \\
\text { Comp_Resources }\end{array}$ & .010 & .157 & .875 & .817 & 12.053 & $* * *$ & .011 & .000 & .011 \\
\hline SCPDC to Comp_Risk & .420 & 6.918 & $* * *$ & .576 & 10.067 & $* * *$ & .484 & .235 & .484 \\
\hline $\begin{array}{l}\text { SCPDC to Comp } \\
\text { Complexity }\end{array}$ & .538 & 8.306 & $* * *$ & .476 & 7.565 & $* * *$ & .615 & .379 & .615 \\
\hline $\begin{array}{l}\text { SCPDC to Financial } \\
\text { Benefit }\end{array}$ & & & & & & & & & .246 \\
\hline $\begin{array}{l}\text { SCPDC to Operational } \\
\text { Efficiency }\end{array}$ & & & & & & & & & .259 \\
\hline SCPDC to Growth Factors & & & & & & & & & .213 \\
\hline ILICU to Financial Benefit & 1.296 & 14.090 & $* * *$ & .215 & 6.875 & $* * *$ & .855 & .731 & .855 \\
\hline $\begin{array}{l}\text { ILICU to Operational } \\
\text { Efficiency }\end{array}$ & 1.328 & 14.248 & $* * *$ & .144 & 4.876 & $* * *$ & .900 & .810 & .900 \\
\hline ILICU to Growth Factors & 1.000 & & & .288 & 10.117 & $* * *$ & .740 & .547 & .740 \\
\hline \multicolumn{10}{|c|}{ LARGE SC OPERATIVES } \\
\hline SCPDC to ILICU & .170 & 4.117 & $* * *$ & .563 & 4.897 & $* * *$ & .221 & .049 & .221 \\
\hline SCPDC to Comp_Control & .573 & 3.760 & $* * *$ & .478 & 2.906 & .004 & .638 & .407 & 638 \\
\hline $\begin{array}{l}\text { SCPDC to } \\
\text { Comp_Resources }\end{array}$ & .072 & .593 & .554 & .953 & 7.692 & $* * *$ & .074 & .005 & .074 \\
\hline SCPDC to Comp_Risk & .391 & 3.293 & $* * *$ & .553 & 5.392 & $* * *$ & .465 & .216 & .465 \\
\hline $\begin{array}{l}\text { SCPDC to } \\
\text { Comp_Complexity }\end{array}$ & .461 & 2.941 & .003 & 1.225 & 6.409 & $* * *$ & .384 & .148 & .384 \\
\hline $\begin{array}{l}\text { SCPDC to Financial } \\
\text { Benefit }\end{array}$ & & & & & & & & & .195 \\
\hline $\begin{array}{l}\text { SCPDC to Operational } \\
\text { Efficiency }\end{array}$ & & & & & & & & & .204 \\
\hline $\begin{array}{l}\text { SCPDC to Growth } \\
\text { Factors }\end{array}$ & & & & & & & & & .174 \\
\hline ILICU to Financial Benefit & 1.334 & 10.729 & $* * *$ & .298 & 4.452 & $* * *$ & .883 & .779 & .883 \\
\hline $\begin{array}{l}\text { ILICU to Operational } \\
\text { Efficiency }\end{array}$ & 1.205 & 10.976 & $* * *$ & .149 & 3.061 & .002 & .923 & .852 & .923 \\
\hline ILICU to Growth Factors & 1.000 & & & .361 & 6.446 & $* * *$ & .788 & .621 & .788 \\
\hline
\end{tabular}

Supply Chain Performance Differential Capability - Variant Model

(Note: $* * *=p \leq 0.001$ and is very significant; $p \leq 0.05$ is significant) 
Table 5(b). SEM Results - Small SC Operatives verses Large Operatives

\begin{tabular}{|c|c|c|c|c|c|c|c|c|c|}
\hline Path & $\begin{array}{l}\text { Unst } \\
\text { RW }\end{array}$ & $\mathbf{t}$ & $\mathbf{p}$ & Var & $\mathbf{t}$ & $\mathbf{p}$ & $\begin{array}{c}\text { St } \\
\text { RW }\end{array}$ & $\begin{array}{l}\text { Sq. } \\
\text { MC }\end{array}$ & $\begin{array}{c}\text { Std } \\
\text { Total } \\
\text { Effects }\end{array}$ \\
\hline \multicolumn{10}{|c|}{ SMALL SC OPERATIVES } \\
\hline SCDC to ILICU & 0.17 & 3.94 & $* * *$ & 0.32 & 6.852 & $* * *$ & .287 & 0.083 & 0.287 \\
\hline $\begin{array}{l}\text { SCDC to } \\
\text { Comp_Reconfigure }\end{array}$ & 0.679 & 8.123 & $* * *$ & 0.55 & 5.503 & $* * *$ & 0.675 & 0.456 & 0.675 \\
\hline $\begin{array}{l}\text { SCDC to } \\
\text { Comp_Collaborate }\end{array}$ & 0.384 & .5 .621 & $* * *$ & 0.725 & 10.517 . & $* * *$ & 0.411 & 0.169 & 0.411 \\
\hline $\begin{array}{l}\text { SCDC to } \\
\text { Comp_Adapt }\end{array}$ & 0.242 & 4.459 & $* * *$ & 0.504 & 11.198 & $* * *$ & 0.322 & 0.104 & 0.322 \\
\hline $\begin{array}{l}\text { SCDC to } \\
\text { Comp_Agility }\end{array}$ & 0.52 & 7.413 & $* * *$ & 0.531 & 7.676 & $* * *$ & 0.581 & 0.337 & 0.581 \\
\hline $\begin{array}{l}\text { SCDC to Financial } \\
\text { Benefit }\end{array}$ & & & & & & & & & 0.248 \\
\hline SCDC to & & & & & & & & & \\
\hline $\begin{array}{l}\text { Operational } \\
\text { Efficiency }\end{array}$ & & & & & & & & & 0.256 \\
\hline $\begin{array}{l}\text { SCDC to Growth } \\
\text { Factors }\end{array}$ & & & & & & & & & 0.211 \\
\hline $\begin{array}{l}\text { ILICU to Financial } \\
\text { Benefit }\end{array}$ & 1.305 & 14.132 & $* * *$ & 0.205 & 6.58 & $* * *$ & 0.862 & 0.743 & 0.862 \\
\hline ILICU to & & & & & & & & & \\
\hline $\begin{array}{l}\text { Operational } \\
\text { Efficiency }\end{array}$ & 1.314 & 14.237 & $* * *$ & 0.154 & 5.258 & $* * *$ & 0.892 & 0.796 & 0.892 \\
\hline $\begin{array}{l}\text { ILICU to Growth } \\
\text { Factors }\end{array}$ & 1 & & & 0.286 & 10.09 & $* * *$ & 0.741 & 0.549 & 0.741 \\
\hline
\end{tabular}

LARGE SC OPERATIVES

\begin{tabular}{|c|c|c|c|c|c|c|c|c|c|}
\hline SCDC to ILICU & 0.17 & 3.94 & $* * *$ & 0.57 & 4.911 & $* * *$ & 0.219 & 0.048 & 0.219 \\
\hline $\begin{array}{l}\text { SCDC to } \\
\text { Comp_Reconfigure }\end{array}$ & 0.56 & 3.581 & $* * *$ & 0.922 & 5.033 & $* * *$ & 0.504 & 0.254 & 0.504 \\
\hline $\begin{array}{l}\text { SCDC to } \\
\text { Comp_Collaborate }\end{array}$ & 0.516 & 3.742 & $* * *$ & 0.62 & 4.387 & $* * *$ & 0.548 & 0.301 & 0.548 \\
\hline $\begin{array}{l}\text { SCDC } \\
\text { Comp_Adapt }\end{array}$ & 0.168 & 1.592 & $* * *$ & 0.679 & 7.425 & $* * *$ & 0.199 & 0.04 & 0.199 \\
\hline $\begin{array}{ll}\text { SCDC } & \text { to } \\
\text { Comp_Agility } & \end{array}$ & 0.423 & 3.274 & $* * *$ & 0.769 & 5.943 & $* * *$ & 0.435 & 0.189 & 0.435 \\
\hline
\end{tabular}


SCDC to Financial

Benefit

Operational

Efficiency

SCDC to Growth

Factors

ILICU to Financial

Benefit

$$
1.327 \quad 10.766 \quad * * *
$$

0.304

4.527

$* * *$

0.881

0.776

0.881

ILICU to

Operational

1.20

\subsection{5}

$* * *$

0.146

2.998

0.003

$\begin{array}{ll}0.925 & 0.856\end{array}$

0.925

Efficiency

ILICU to Growth

Factors

1

0.36

6.43

$* * *$

0.79

0.625

0.79

Supply Chain Dynamic Capability Variant Model

(Note: $* * *=p \leq 0.001$ and is very significant; $p \leq 0.05$ is significant) 


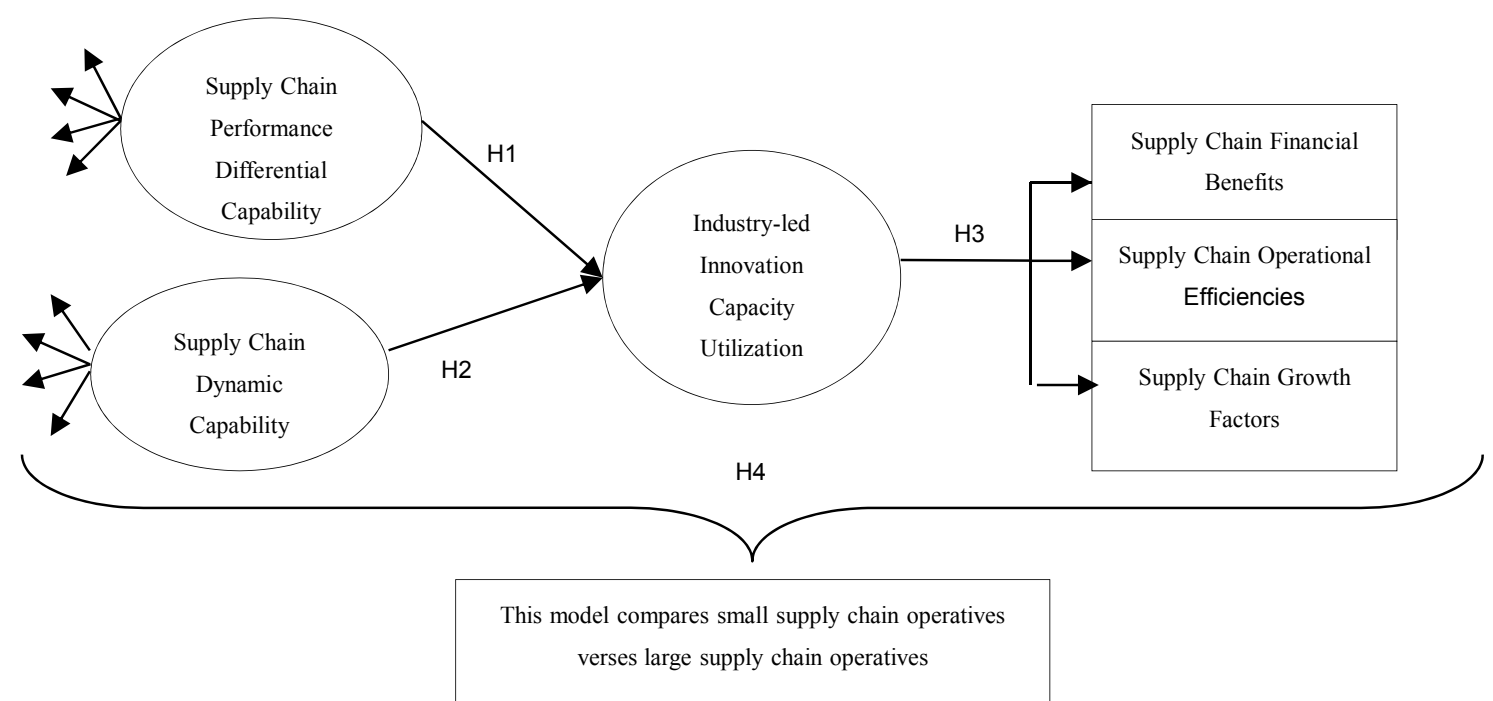

Figure 1. A Research Framework and Hypothesized Relationships 
Appendix 1

\title{
SURVEY MEASURES
}

SUPPLY CHAIN PERFORMANCE DIFFERENTIAL CAPABILITY (SCPDC)

- Complexity

\author{
Measure Scale: 5 Point Likert Scale - (1) Not Important - to - (5) Very Important
}

Question1: Indicate how important the following activities are to participating in the Australian beef supply chain?

- Joint day-to-day management of internal and external business activities;

- Maintaining accurate accounting and financial controls; Joint strategic business planning

- Joint staff training and education services; conducting research and industry innovation exercises; joint marketing advertising and promotion activities;

- Joint activities relating to purchasing and procurement; transport, distribution and warehousing; stock/inventory management (including livestock; sales; joint scheduling of new equipment, parts and machinery purchases

- Assisting customers/suppliers to ensure Sales stay buoyant

- Sharing access to services such as professional services; joint scheduling maintenance of plant and equipment;

- $\quad \underline{\text { Risk }}$

Measure Scale: 5 Point Likert Scale - (1) Strongly Disagree- to - (5) Strongly Agree

Question 2: Indicate your level of agreement with the following points of view/statements about managing risk in the Australian beef supply chain?

- We believe our customers and suppliers are trustworthy and that they understand and support our supply chain activities.

- We are willing to devote extra effort to our customers and suppliers relationships;

- We believe our customers and suppliers are generally knowledgeable and understand our business.

- We share much sensitive information with our customers and suppliers

- $\quad$ Control

Measure Scale: 5 Point Likert Scale - (1) Not Important - to - (5) Very Important

Question 3: Indicate how important the following measures are for controlling the performance of the Australian beef supply chain?

- Measuring customer satisfaction; customer complaints; end-user consumer satisfaction

- Measuring supplier performance; On-time deliveries; product quality; production lead-times

- Financial information relating to processing costs; inventory costs; cash flow management; business profitability

- Transport information relating to transport errors; back orders; stock-out rates; fill rates; re-order lead times; changes in consumer behaviour

- Staff absenteeism; staff moral; staff turnover; workplace health and safety incidents; skill levels; training requirements

- $\quad$ Resources (e-Resources)

Measure Scale: 5 Point Likert Scale - (1) No Impact - to - (5) Significant Impact

Question 4: Indicate to what extent the following factors limit activities of the Australian beef supply chain in relation to its access to resources (such as the Internet and electronic business systems)?

- Possessing technical knowledge and capability to use the Internet and electronic business software

- Availability of technical assistance to select and install equipment and service and fix problems

- Lack of Bandwidth

- Faults in telecommunications equipment

SUPPLY CHAIN DYNAMIC CAPABILITY (SCDC)

\section{- Reconfiguration}


Measure Scale: 5 Point Likert Scale - (1) Not Important - to - (5) Very Important

Question 1: Indicate the extent to which your company agrees with the following statements regarding relationships within the Australian beef industry supply chain?

- Flexibility within relationships allows for the introduction of new products, processes and systems across the Australian beef SC

- We learn from our customers in the SC in meeting market demand

- Our customers are committed to improve our competitive position in the market

- We learn from our suppliers in the SC in meeting market demand

- Our suppliers are committed to improve our competitive position in the market

- Everyone in the SC should work to provide volume continuity

- Everyone in the SC should work to provide better quality product

- Everyone in the SC should work to improve timeliness for the customer

- Everyone in the SC should work to improve timeliness for the supply chain

- Everyone in the SC should work to improve cost reductions for supply chain members

- Everyone in the SC should work to improve cost reductions for customers

- Everyone in the SC should work to being first to market

- It is important for SC members to adapt to market conditions

- It is important for SC members to adapt to new consumer directions

- $\quad$ Collaboration

\author{
Measure Scale: 5 Point Likert Scale - (1) Strongly Disagree- to - (5) Strongly Agree
}

Question 2: Indicate how important it is for the Australian beef supply chain to collaborate across the following activities to meet Market Demand?

- Cooperate with growers

- Cooperate with feedlots

- Cooperate with saleyards

- Cooperate with processors

- Cooperate with manufacturers

- Cooperate with agents, vets, professional services, logistics

- Cooperate with wholesalers and retail, export operators

- Cooperate with suppliers in product, process and/or systems innovation

- Working cooperatively with customers and suppliers to ensure the industry is competitive overall

- Cooperate with customers to engage in future planning and growth strategies

- Cooperate with suppliers to engage in future planning for growth

- Cooperate with customers in product, process and/or systems innovation

- Cooperate with seedstock producers - Drop

- $\quad$ Adaptability

Measure Scale: 5 Point Likert Scale - (1) Not Often - to - (5) Always)

Question 4: Indicate how often the supply chain jointly engages in the following activities to adapt and integrate to meet Market Demand?

- Managing Inventory

- Working Towards best practice in SC activities

- Coordinate changes in production, processing and retail activities to meet deadlines

- Activities involved in securing stock and inventory management; sales; export services

- Improving SC traceability and work processes

- Activities involved in research, development and business innovation

- Activities involved in new banking and finances practices

- Activities involved in new methods of information sharing; marketing, advertising and promotion activities

- Activities involved in purchase of new parts and machinery;

- Activities involved in strategic planning;

- Activities involved in designing business management and customer communication practices

- Activities involved in designing staff training and education

- Activities involved in planning purchasing and procurement; 
- Activities involved in planning transport, warehousing and logistics;

- Activities involved in the outsourcing operational and sales services

- Activities involved in the provisions of professional services

- Activities involved in the provisions of services for plant and equipment maintenance scheduling

- $\quad \underline{\text { Agility }}$

Measure Scale: 5 Point Likert Scale - ((1) Not Important - to - (5) Very Important

Question 3: Indicate how important it is for the beef supply chain to jointly engage in the following activities to meet Market Demand?

- Flexibility in new product design

- Volume flexibility

- Delivery flexibility

- Product mix flexibility

INDUSTRY-LED INNOVATION CAPACITY UTILIZATION (ILICU)

- $\quad$ Financial Benefits (FB)

Measure Scale: 5 Point Likert Scale - (1) Not Important - to - (5) Very Important

Question 1: Indicate how important utilizing supply chain innovation capacity such as widespread use of the Internet and electronic business systems has been in obtaining the following supply chain benefits?

- Reduced operating costs

- Increased profits/business turnover

- Operational Efficiencies (OP)

Measure Scale: 5 Point Likert Scale - (1) Not Important - to - (5) Very Important

Question 2: Indicate how important utilizing supply chain innovation capacity such as widespread use of the Internet and electronic business systems has been in obtaining the following supply chain benefits?

- More efficient use of time

- Improved operating efficiencies

- Enabling more frequent contract between customers/suppliers and staff

- Growth Factors (GF)

Measure Scale: 5 Point Likert Scale - (1) Not Important - to - (5) Very Important

Question 3: Indicate how important utilizing supply chain innovation capacity such as widespread use of the Internet and electronic business systems has been in obtaining the following supply chain benefits?

- Opening up business opportunities in global markets

- Obtaining an overall improved SC performance 